\title{
Experimental studies on the Danxia landscape morphogenesis in Mt. Danxiashan, South China
}

\author{
ZHU Cheng ${ }^{1},{ }^{*} W U$ Li $^{2}$, ZHU Tongxin ${ }^{3}$, HOU Rongfeng ${ }^{4}$, HU Zhinong ${ }^{5}$, \\ TAN Yan ${ }^{1}$, SUN Wei ${ }^{1}$, JIA Tianjiao ${ }^{1}$, PENG Hua ${ }^{6}$ \\ 1. School of Geographic and Oceanographic Sciences, Nanjing University, Nanjing 210023, China; \\ 2. College of Territorial Resources and Tourism, Anhui Normal University, Wuhu 241002, Anhui, China; \\ 3. Department of Geography, University of Minnesota-Duluth, MN 55812, USA; \\ 4. Administrative Committee of Danxiashan Scenic Spot, Shaoguan 512300, Guangdong, China; \\ 5. Nanjing Hydraulic Research Institute, Nanjing 210029, China; \\ 6. School of Geography and Planning, Sun Yat-Sen University, Guangzhou 510275, China
}

\begin{abstract}
The formation of Danxia landscapes is too slow to be observed in our life time and the paleoclimates in which Danxia landscapes developed are significantly different from the present. Thus, this study adopted experimental approaches to examine the lithological and paleoclimatic control on the formation of various landscape morphologies in the Mt. Danxiashan, South China. A total of 122 rock samples were collected from a range of Danxia landscape morphologies such as white spots, small and large through caves, honeycomb caves, horizontal grooves, natural bridges, stone pillars, and squama stones. Analyses of the collected samples were conducted in different kinds of experiments, including uniaxial mechanical strength testing; rock resistance against sulfuric acid erosion, freezing, and thawing; X-ray fluorescence spectrometry (XRF) analysis; inductively coupled plasma mass spectrometry (ICP-MS) analysis; and identification analysis under a polarizing microscope. The results indicated that the formation of the various Danxia landscape morphologies could result from one or more of the following processes: differential erosion due to lithological difference, chemical dissolution and recrystallization, freezing and thawing actions, acid corrosion, weathering, lateral erosion of river flows, and tectonic uplifts. Water erosion in humid monsoon climate and the alternations of intensive freezing and thawing actions in the Quaternary glacial stages and the interglacial stages could have had great influences on the formation of Danxia landscape topographies.
\end{abstract}

Keywords: experimental studies; rock properties; Danxia landform; paleoclimates; China

Received: 2014-07-13 Accepted: 2014-11-20

Foundation: National Natural Science Foundation of China, No.41371204; No.41171163; No.41401216; National Science and Technology Basic Special Key Project, No.2013FY111900; Foundation of State Key Laboratory of Loess and Quaternary Geology, Institute of Earth Environment, CAS, No.SKLLQG1206; No.SKLLQG1422; National Basic Science Personnel Training Project, No.J1103408; Foundation of Modern Analysis Center, Nanjing University, No.0422171010; Priority Academic Program Development of Jiangsu Higher Education Institutions, No.PAPD

Author: Zhu Cheng (1954-), PhD and Professor, specialized in geomorphology and Quaternary geology.

E-mail: zhuchengnj@126.com

*Corresponding author: Wu Li (1985-), PhD, E-mail: jedi-wuli@163.com 


\section{Introduction}

The Danxia landform, put forward by Chinese scholars (Chen, 1939; Huang, 1982) and named after the Danxiashan Mountain (Mt. Danxiashan) in Guangdong Province of China, is developed in the strata of red continental sandstones of the Cretaceous period, including such morphologic shapes as horizontal grooves, red cliffs, mesas, stone walls, stone peaks, stone pillars, narrow gorges, rock lanes, and rock caves (Zhu et al., 2010; Peng et al., 2013; Zhao et al., 2014). Over 1000 Danxia landform sites have been discovered in China (Huang et al., 1992; Huang, 2014) and six of them, including Danxiashan, Chishui, Taining, Langshan, Longhushan, and Jianglangshan, were inscribed as the World Heritage Sites by UNESCO in 2010, which have attracted great attention and boosted the tourism of the regions. However, research on the landscape morphogenesis of the Danxia landform has been lagged far behind the progress of tourism development in the regions (Peng, 2001; Zhu et al., 2009; Huang, 2010; Ouyang et al., 2011) and has been largely published in Chinese (Chen, 1935; Zeng, 1978; Huang, 1982; Peng, 2001; Zhu et al., 2009). The methods employed by the previous studies are basically field investigations except for identifications of lithological slices in labs (Zhang and Zhang, 1986; Bureau of Geology of Foshan City and 706 Geological Team of Bureau of Geology of Guangdong Province, 2008; Chen et al., 2010). As a type of rocky landform, the development processes of the Danxia landscapes are very slow for us to observe in our life time and the paleoclimates in which the landscapes formed are also significantly different from the present. The Mt. Danxiashan is presently humid subtropical climates but was dominated by periglacial conditions in the Quaternary glacial periods and frequently influenced by volcanic eruptions in the region in Mesozoic (Zhu, 2000; Shi et al., 1989; Zhu et al., 2012). In this study, we adopted experimental approaches to study the landscape morphogenesis by testing rock strength of the samples taken from all major types of Danxia landscape morphologies under freezing-thaw, acidic and dry-wet conditions, and by examining the lithological differences of the various Danxia landscapes. An understanding of the Danxia landscape morphogenesis is not only a contribution to the field of geomorphology but also can meet the increasing curiosity of tourists about the spectacular scenes associated with the Danxia landform.

\section{Study site}

Mt. Danxiashan is located in Renhua County of Shaoguan City in Guangdong Province $\left(24^{\circ} 51^{\prime} 48^{\prime \prime}-25^{\circ} 04^{\prime} 12^{\prime \prime} \mathrm{N}, 113^{\circ} 36^{\prime} 25^{\prime \prime}-113^{\circ} 47^{\prime} 53^{\prime \prime} \mathrm{E}\right)$, covering a total area of $292 \mathrm{~km}^{2}$ and comprising more than 600 peaks of the Danxia landscape and a density of stone peaks, stone fortresses, stone walls and stone pillars up to 20 per square km (Figure 1). It has an average annual precipitation of $1700 \mathrm{~mm}$ or so. Under warm and wet climatic conditions, subtropical evergreen broad-leaved forests cover most of the region, and subtropical monsoonal rainforest can be found growing in the ravines as well. Mt. Danxiashan is famous for its beauty and has earned the titles of world natural heritage site, global geopark, state reserve, national AAAAA scenic spot, and national geopark. The NNE Shaoguan-Renhua fault is a large regional fault passing through the middle of the Danxia Basin, dividing the region into the eastern and western basins (Figure 1). Under all kinds of internal and external forces, various spectacular Danxia landscape topographies came into view as can be seen today. Table 1 
shows the stratum and lithology in the Mt. Danxiashan region.

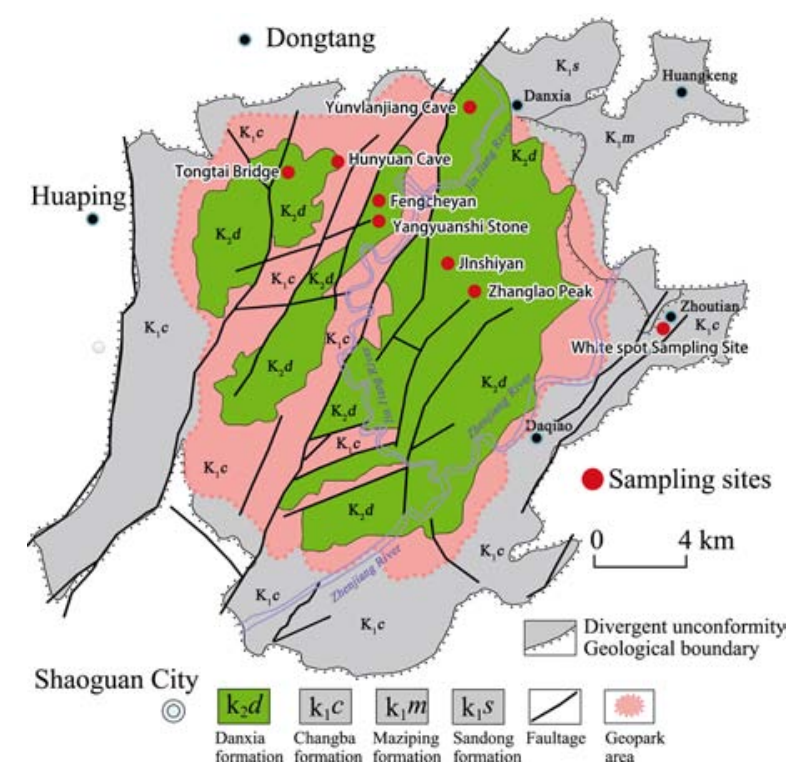

Figure 1 Location map of Mt. Danxiashan in Guangdong and the research sites of Danxia landscape topographies

Table 1 The features of the stratum and lithology in the Mt. Danxiashan area in South China

\begin{tabular}{|c|c|c|c|}
\hline $\begin{array}{l}\text { Stratum times } \\
\text { and signs }\end{array}$ & $\begin{array}{l}\text { Stratum } \\
\text { names }\end{array}$ & $\begin{array}{c}\text { Stratum } \\
\text { thickness (m) }\end{array}$ & Lithological features \\
\hline $\mathrm{K}_{2} \mathrm{~d}$ & $\begin{array}{l}\text { Danxia } \\
\text { Formation }\end{array}$ & 1000 & $\begin{array}{l}\text { The interbedded-layers consisting of purple-red and brick-red } \\
\text { thick-layer and huge-thick-layer conglomerates, conglomer- } \\
\text { ate-containing sandstones, feldspar quartz sandstones of different } \\
\text { grains, quartz power sandstones mixed with sandy feldspars and power } \\
\text { sandy mudstones, featured by the development of parallel stratums and } \\
\text { large interlaced stratums. }\end{array}$ \\
\hline $\mathrm{K}_{1} c$ & $\begin{array}{l}\text { Changba } \\
\text { Formation }\end{array}$ & $2000-2500$ & $\begin{array}{l}\text { Construction of red molasses deposited at the feet of mountains or in } \\
\text { lakes, with the inter-layers of such rocks as conglomerate, sandy con- } \\
\text { glomerate, powdered sandy mudstone, calcareous mudstone, laminated } \\
\text { fine sandstone, powdered sandstone, gray-brown and purple-red con- } \\
\text { glomerate and feldspar sandstones of different grains and red sandy } \\
\text { conglomerate. }\end{array}$ \\
\hline $\mathrm{K}_{1} m$ & $\begin{array}{l}\text { Maziping } \\
\text { Formation }\end{array}$ & 645-994 & $\begin{array}{l}\text { Purple-red sandstones, powdered sandstones, muddy sandstones, } \\
\text { shales, etc., with conglomerate-containing sandstones and conglomer- } \\
\text { ates at the bottom. }\end{array}$ \\
\hline $\mathrm{K}_{1} S$ & $\begin{array}{l}\text { Sandong } \\
\text { Formation }\end{array}$ & $54-128$ & $\begin{array}{l}\text { Dark purple-red volcanite and volcaniclastic rocks, with the low- } \\
\text { er-layers of such rocks as rhyolitic tuff, andesite and basalt, and with } \\
\text { the upper-inter-layers of such rocks as tuff, tuffaceous sandstone, } \\
\text { purple-red powdered sandstone and muddy powdered sandstone, etc. }\end{array}$ \\
\hline
\end{tabular}

\section{Sampling and experimental methods}

\subsection{Sampling sites}

As shown in Figures 2-4 and Tables 2-8, 122 rock samples were collected from sandstones, conglomerates and mudstones at the large horizontal groove in Jinshiyan Crag of Zhanglao- 
feng Peak, the through cave in Fengcheyan of the west slope of Yangyuanshan Peak, the Yangyuanshi stone pillar in the east side of Yangyuanshan Peak, the Tongtai natural bridge in the north side of Yangyuanshan Peak, Hunyuan Cave in the west end of Shiziyan, Yunvlanjiang Cave, and Yamayan in Yueling Village of Zhoutian Town in Mt. Danxiashan.
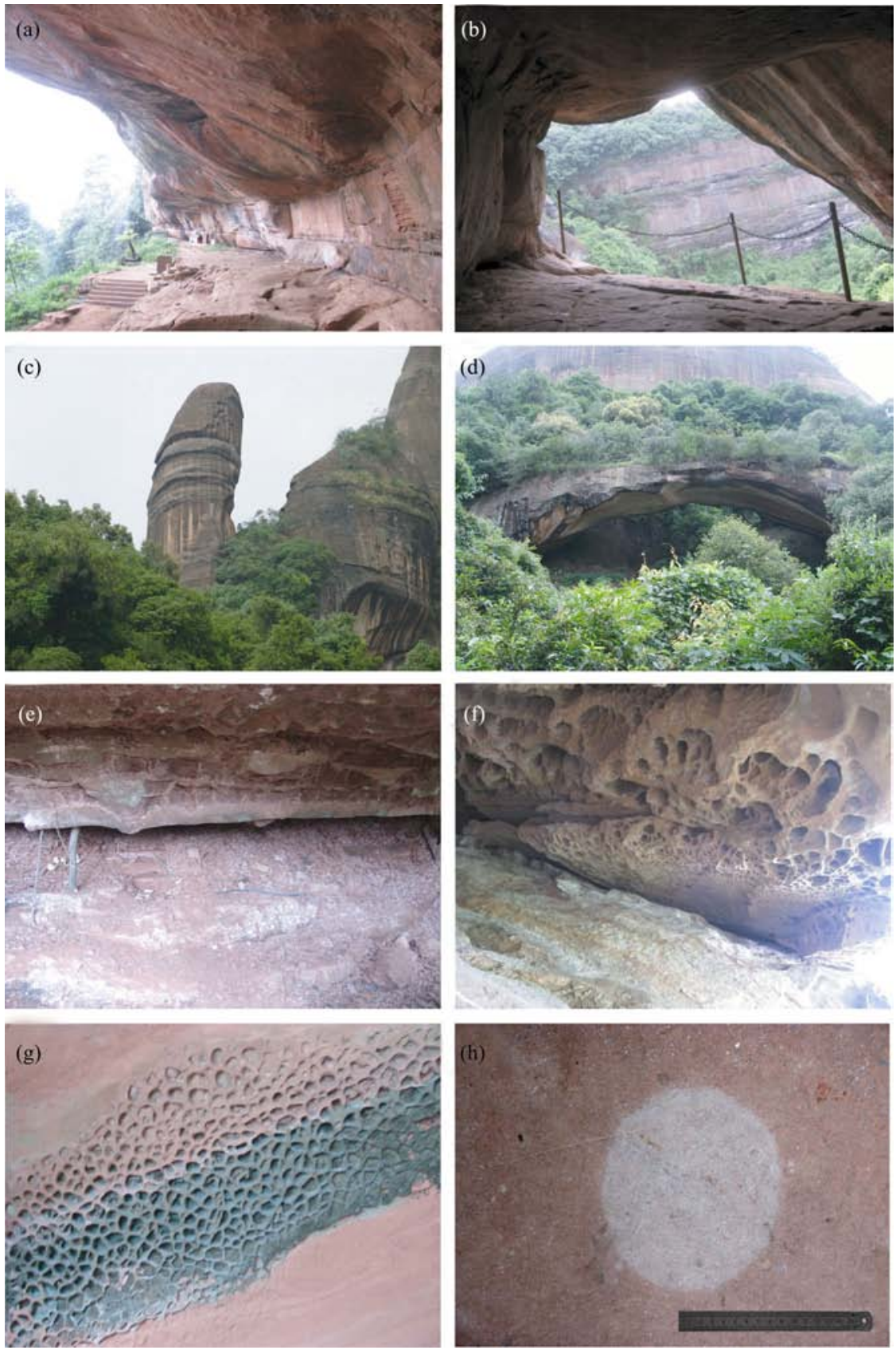

Figure 2 The features of the Danxia landscape topographies at sampling sites. (a) The large horizontal groove of Jinshiyan in Zhanglao Peak; (b) The through cave of Fengcheyan in Yangyuanshan Peak; (c) The Yangyuanshi independent stone pillar in Yangyuanshan Peak; (d) The Tongtai natural bridge in Yangyuanshan Peak; (e) The purple-red mudstone groove of Hunyuan Cave in Shiziyan; (f) The honeycomb cave of Yunvlanjiang; (g) The dragon squamose stone in the horizontal groove of Jinshiyan in Zhanglao Peak; (h) The white spot of Yamayan in Yueling Village, Zhoutian County 

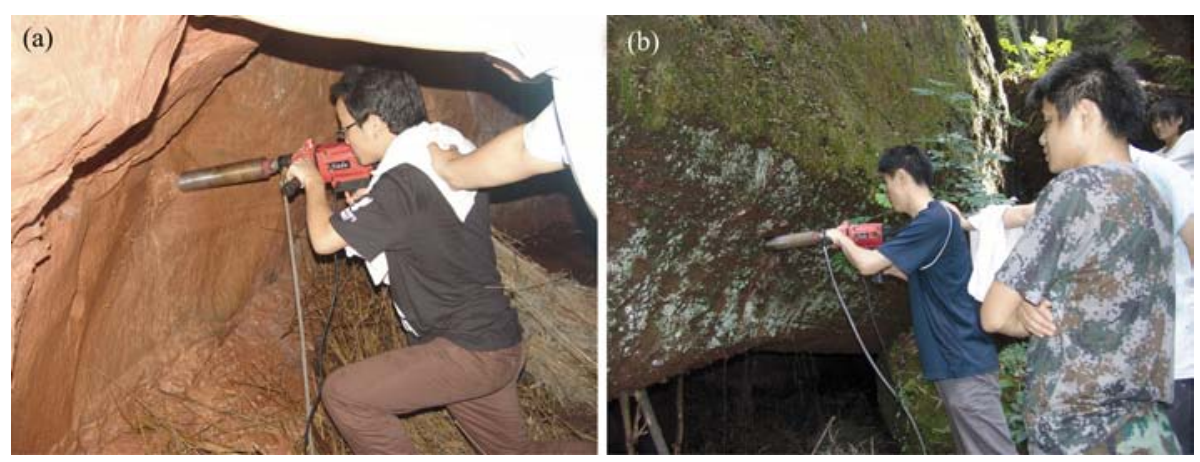

Figure 3 The sites for drilling cores in Mt. Danxiashan

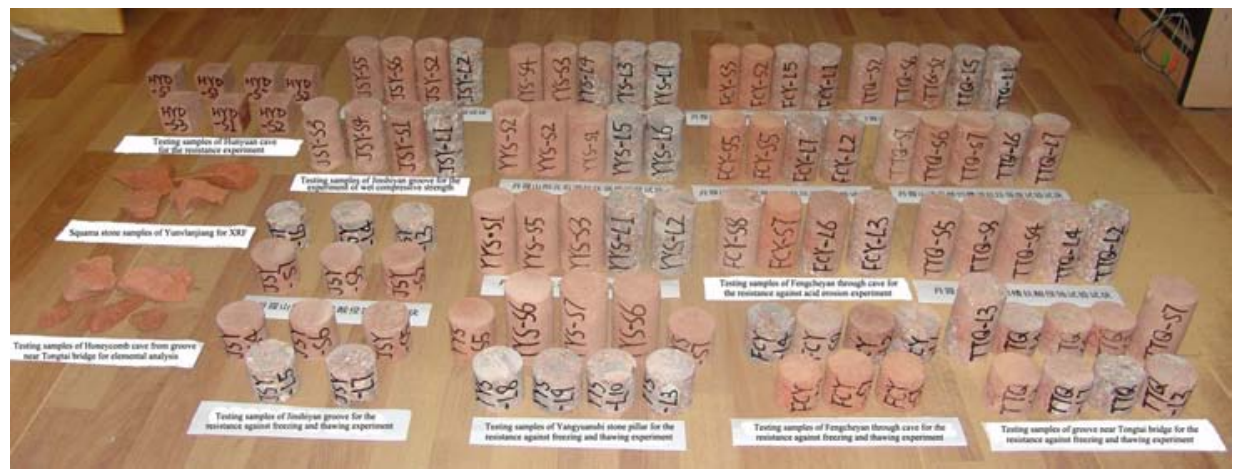

Figure 4 The part of samples with uniform specification after having been cut off

\subsection{Experimental methods}

A range of experiments were performed on the collected samples, including uniaxial mechanical strength testing; rock resistance against sulfuric acid erosion, freezing and thawing; $\mathrm{X}$-ray fluorescence spectrometry (XRF) analysis; inductively coupled plasma mass spectrometry (ICP-MS) analysis; sandstone, conglomerate and mudstone grinding slices for identification analysis under a polarizing microscope.

The procedures and steps for the uniaxial mechanical strength and the rock's resistance against sulfuric acid, freezing, and thawing experiments followed the DL/T5368-2007 Standards of Rock Experiment Procedures of Water Conservancy and Hydropower Engineering of the People's Republic of China promulgated by the National Development and Reform Commission (NDRC) of the PRC (2007), as well as the Standards of JTGE41-2005 of Highway Engineering Rocks of the PRC promulgated by the Ministry of Transport of the PRC (2005), and were described in detail elsewhere (Zhu et al., 2010). In brief, the uniaxial mechanical strength of rocks under different conditions was tested by the YE-2000 hydraulic pressure testing machine (Figure 5). A total of 40 samples were tested, including 26 sandstones (13 dry vs. 13 saturated with water) and 14 conglomerate samples (7 dry vs. 7 saturated with water). In the experiments, the sample gesture and stress direction must be considered. Table 2 shows some of the results of the uniaxial mechanical strengths tests.

During the resistance against acid erosion experiments, sulfuric acid solutions with three different $\mathrm{pH}$ values (2, 3, and 4) were prepared in the laboratory; and then 12 sandstone 
Table 2 Experimental records of ability to resist against uniaxial mechanical strength of rocks in the research sites

\begin{tabular}{|c|c|c|c|c|}
\hline \multicolumn{2}{|c|}{$\begin{array}{l}\text { Formation of sampling sites and developmental } \\
\text { geomorphologic position }\end{array}$} & \multirow{2}{*}{$\begin{array}{c}\begin{array}{c}\text { Lithology and } \\
\text { number }\end{array} \\
\text { FCY-S2 }\end{array}$} & \multirow{2}{*}{$\begin{array}{c}\begin{array}{c}\text { Destructive } \\
\text { load }(K N)\end{array} \\
26.10\end{array}$} & \multirow{2}{*}{$\begin{array}{c}\begin{array}{c}\text { Strength to dry and } \\
\text { wet compressive } \\
\text { strength }(M P a)\end{array} \\
\text { Dry } 11.80\end{array}$} \\
\hline \multirow{8}{*}{$\begin{array}{l}\text { Through cave of } \\
\text { Fengcheyan, } \mathrm{K}_{2} d \\
\text { Danxia Formation }\end{array}$} & \multirow{4}{*}{$\begin{array}{l}\text { Sandstone in } \\
\text { through cave }\end{array}$} & & & \\
\hline & & FCY-S5 & 21.10 & Dry 9.74 \\
\hline & & FCY-S3 & 8.10 & Wet 3.92 \\
\hline & & FCY-S5 & 7.10 & Wet 3.66 \\
\hline & \multirow{4}{*}{$\begin{array}{l}\text { Conglomerate under } \\
\text { through cave }\end{array}$} & FCY-L1 & 88.40 & Dry 36.65 \\
\hline & & FCY-L5 & 99.50 & Dry 41.14 \\
\hline & & FCY-L2 & 73.60 & Wet 30.35 \\
\hline & & FCY-L7 & 79.80 & Wet 32.76 \\
\hline \multirow{10}{*}{$\begin{array}{l}\text { Yangyuanshi stone pillar, } \\
\mathrm{K}_{2} d \text { Danxia Formation }\end{array}$} & \multirow{6}{*}{$\begin{array}{l}\text { Sandstone of } \\
\text { Yangyuanshi stone pillar }\end{array}$} & YYS-S1 & 70.90 & Dry 28.52 \\
\hline & & YYS-S2 & 120.00 & Dry 49.30 \\
\hline & & YYS-S3 & 99.40 & Dry 40.75 \\
\hline & & YYS-S1 & 62.20 & Wet 25.56 \\
\hline & & YYS-S2 & 55.10 & Wet 22.75 \\
\hline & & YYS-S3 & 60.00 & Wet 24.67 \\
\hline & \multirow{4}{*}{$\begin{array}{l}\text { Conglomerate of } \\
\text { Yangyuanshi stone pillar }\end{array}$} & YYS-L4 & 112.20 & Dry 45.82 \\
\hline & & YYS-L7 & 146.60 & Dry 59.61 \\
\hline & & YYS-L5 & 119.90 & Wet 48.94 \\
\hline & & YYS-L6 & 129.10 & Wet 52.91 \\
\hline \multirow{8}{*}{$\begin{array}{l}\text { Jinshiyan groove, } \mathrm{K}_{2} d \\
\text { Danxia Formation }\end{array}$} & \multirow{6}{*}{$\begin{array}{l}\text { Sandstone in Jinshiyan } \\
\text { groove }\end{array}$} & JSY-S2 & 131.80 & Dry 56.35 \\
\hline & & JSY-S5 & 149.00 & Dry 62.46 \\
\hline & & JSY-S6 & 143.50 & Dry 60.14 \\
\hline & & JSY-S1 & 114.20 & Wet 46.92 \\
\hline & & JSY-S3 & 115.00 & Wet 47.92 \\
\hline & & JSY-S4 & 102.50 & Wet 43.17 \\
\hline & \multirow{2}{*}{$\begin{array}{l}\text { Conglomerate of Jinshi- } \\
\text { yan groove }\end{array}$} & JSY-L2 & 98.90 & Dry 41.54 \\
\hline & & JSY-L1 & 68.50 & Wet 29.01 \\
\hline \multirow{10}{*}{$\begin{array}{l}\text { Groove next to Tongtai } \\
\text { bridge, } \mathrm{K}_{2} d \text { Danxia } \\
\text { Formation }\end{array}$} & \multirow{6}{*}{$\begin{array}{l}\text { Sandstone in groove } \\
\text { next to Tongtai bridge }\end{array}$} & TTQ-S2 & 84.00 & Dry 34.91 \\
\hline & & TTQ-S6 & 39.20 & Dry 17.17 \\
\hline & & TTQ-S7 & 86.90 & Dry 35.75 \\
\hline & & TTQ-S2 & 20.20 & Wet 8.76 \\
\hline & & TTQ-S6 & 60.20 & Wet 25.00 \\
\hline & & TTQ-S7 & 33.10 & Wet 13.76 \\
\hline & \multirow{4}{*}{$\begin{array}{l}\text { Conglomerate of groove } \\
\text { next to Tongtai bridge }\end{array}$} & TTQ-L1 & 109.40 & Dry 45.47 \\
\hline & & TTQ-L5 & 82.10 & Dry 34.34 \\
\hline & & TTQ-L6 & 82.00 & Wet 33.94 \\
\hline & & TTQ-L7 & 48.80 & Wet 20.38 \\
\hline \multirow{4}{*}{$\begin{array}{l}\text { Groove of Hunyuan } \\
\text { Cave, } K_{2} d \text { Danxia } \\
\text { Formation }\end{array}$} & \multirow{4}{*}{$\begin{array}{l}\text { Sandstone in groove of } \\
\text { Hunyuan Cave }\end{array}$} & HYD-S1 & 167.00 & Dry 69.13 \\
\hline & & HYD-S2 & 143.50 & Dry 65.03 \\
\hline & & HYD-S1 & 160.00 & Wet 66.56 \\
\hline & & HYD-S2 & 151.00 & Wet 61.28 \\
\hline
\end{tabular}


Table 3 Experimental records of ability to resist against acid erosion of rocks in the research sites

\begin{tabular}{|c|c|c|c|c|c|}
\hline $\begin{array}{l}\text { Formation of } \\
\text { sampling sites and } \\
\text { developmental } \\
\text { geomorphologic } \\
\text { position }\end{array}$ & $\begin{array}{l}\text { Lithology } \\
\text { and num- } \\
\text { ber }\end{array}$ & Descriptions of block appearance & $\begin{array}{l}\text { Strength to } \\
\text { average } \\
\text { anti-pressure } \\
\text { before acid } \\
\text { erosion } \\
(\mathrm{MPa})\end{array}$ & $\begin{array}{l}\mathrm{pH} \text { val- } \\
\text { ues of } \\
\text { erosion } \\
\text { media }\end{array}$ & $\begin{array}{l}\text { Strength to } \\
\text { anti-pressure } \\
\text { after acid } \\
\text { erosion } \\
(M P a)\end{array}$ \\
\hline \multirow{4}{*}{$\begin{array}{l}\text { Through cave of } \\
\text { Fengcheyan, } \mathrm{K}_{2} d \\
\text { Danxia Formation }\end{array}$} & FCY-S7 & $\begin{array}{l}\text { Red kernstone, loose, with frag- } \\
\text { ile texture and a few of weather- } \\
\text { ing white spots }\end{array}$ & \multirow[b]{2}{*}{10.77} & 2 & 3.71 \\
\hline & FCY-S8 & $\begin{array}{l}\text { Light red medium sandstone } \\
\text { containing few of conglomerates } \\
\text { with diameter of } 2-8 \mathrm{~mm} \text {, and } \\
\text { conglomerates mainly composed } \\
\text { of limestone }\end{array}$ & & 4 & 27.36 \\
\hline & FCY-L3 & $\begin{array}{l}\text { Grey red conglomerates with } \\
\text { diameter of } 2-8 \mathrm{~mm} \text {, and con- } \\
\text { glomerates composed of lime- } \\
\text { stone and ferriferous-siliceous } \\
\text { rock fragments }\end{array}$ & \multirow[b]{2}{*}{38.90} & 2 & 27.69 \\
\hline & FCY-L6 & $\begin{array}{l}\text { Light red sandstone containing } \\
\text { conglomerate with diameter of } \\
1-6 \mathrm{~mm} \text {, and conglomerates } \\
\text { mainly composed of limestone, } \\
\text { feldspar and siliceous rock frag- } \\
\text { ments with white spots }\end{array}$ & & 4 & 22.55 \\
\hline \multirow{5}{*}{$\begin{array}{l}\text { Yangyuanshi stone } \\
\text { pillar, } \mathrm{K}_{2} d \text { Danxia } \\
\text { Formation }\end{array}$} & YYS-S4 & $\begin{array}{l}\text { Light red medium sandstone, } \\
\text { homogeneous texture without } \\
\text { inclusion }\end{array}$ & \multirow{2}{*}{39.52} & 2 & 26.52 \\
\hline & YYS-S5 & $\begin{array}{l}\text { Light red medium sandstone, } \\
\text { homogeneous texture without } \\
\text { inclusion }\end{array}$ & & 4 & 24.61 \\
\hline & YYS-L1 & $\begin{array}{l}\text { Grey red conglomerates with } \\
\text { diameter of } 0.1-1 \mathrm{~cm} \text {, and con- } \\
\text { glomerates mainly composed of } \\
\text { limestone, quartz, feldspar and } \\
\text { siliceous rock fragments }\end{array}$ & \multirow{3}{*}{51.82} & 2 & 29.79 \\
\hline & YYS-L2 & $\begin{array}{l}\text { Grey red conglomerates with } \\
\text { larger diameter of } 0.2-5 \mathrm{~cm} \text {, and } \\
\text { conglomerates mainly composed } \\
\text { of limestone, quartz, feldspar and } \\
\text { siliceous-quartz rock fragments }\end{array}$ & & 3 & 37.13 \\
\hline & YYS-L3 & $\begin{array}{l}\text { Grey red conglomerates with } \\
\text { diameter of } 2-20 \text { mm, and con- } \\
\text { glomerates mainly composed of } \\
\text { limestone, quartz, feldspar and } \\
\text { siliceous rock fragments }\end{array}$ & & 4 & 58.43 \\
\hline \multirow{3}{*}{$\begin{array}{l}\text { Jinshiyan groove, } \\
\mathrm{K}_{2} d \text { Danxia } \\
\text { Formation }\end{array}$} & JSY-S2 & $\begin{array}{l}\text { Light red feldspar hard } \\
\text { fine-sandstone with compact } \\
\text { texture }\end{array}$ & \multirow{3}{*}{59.65} & 2 & 53.57 \\
\hline & JSY-S3 & $\begin{array}{l}\text { Light red compact hard } \\
\text { fine-sandstone with white spots }\end{array}$ & & 3 & 34.36 \\
\hline & JSY-S7 & $\begin{array}{l}\text { Light red compact hard } \\
\text { fine-sandstone with white } \\
\text { reicnlbation }\end{array}$ & & 4 & 42.93 \\
\hline
\end{tabular}


(Continued)

\begin{tabular}{|c|c|c|c|c|c|}
\hline $\begin{array}{l}\text { Formation of } \\
\text { sampling sites and } \\
\text { developmental } \\
\text { geomorphologic } \\
\text { position }\end{array}$ & $\begin{array}{l}\text { Lithology } \\
\text { and num- } \\
\text { ber }\end{array}$ & Descriptions of block appearance & $\begin{array}{l}\text { Strength to } \\
\text { average } \\
\text { anti-pressure } \\
\text { before acid } \\
\text { erosion } \\
(M P a) \\
\end{array}$ & $\begin{array}{l}\mathrm{pH} \text { val- } \\
\text { ues of } \\
\text { erosion } \\
\text { media }\end{array}$ & $\begin{array}{l}\text { Strength to } \\
\text { anti-pressure } \\
\text { after acid } \\
\text { erosion } \\
(M P a)\end{array}$ \\
\hline & JSY-L3 & $\begin{array}{l}\text { Grey red conglomerates, with } \\
\text { various diameters of } 0.2-3 \mathrm{~cm} \text {, } \\
\text { and consisting of limestone, } \\
\text { feldspar, quartz, siliceous and } \\
\text { calcareous rock fragments }\end{array}$ & & 2 & 40.79 \\
\hline & JSY-L4 & $\begin{array}{l}\text { Grey red conglomerates with } \\
\text { diameter of } 0.2-3 \mathrm{~cm} \text {, and con- } \\
\text { sisting of limestone, feldspar, } \\
\text { quartz and siliceous rock frag- } \\
\text { ments }\end{array}$ & 41.54 & 3 & 53.41 \\
\hline & JSY-L6 & $\begin{array}{l}\text { Grey red conglomerates, with } \\
\text { diameter of } 0.2-3 \mathrm{~cm} \text {, and con- } \\
\text { sisting of limestone, feldspar, } \\
\text { quartz, siliceous and calcareous } \\
\text { rock fragments containing a } \\
\text { piece of brown-yellow mineral } \\
\text { with a diameter of } 3 \mathrm{~cm}\end{array}$ & & 4 & 46.40 \\
\hline \multirow{5}{*}{$\begin{array}{l}\text { Groove next to } \\
\text { Tongtai bridge, } \\
\mathrm{K}_{2} d \text { Danxia } \\
\text { Formation }\end{array}$} & TTQ-S3 & $\begin{array}{l}\text { Light red medium sandstone } \\
\text { containing conglomerates, and } \\
\text { conglomerates mainly composed } \\
\text { of limestone containing feldspar } \\
\text { and quartz }\end{array}$ & \multirow{3}{*}{29.28} & 2 & 23.42 \\
\hline & TTQ-S4 & $\begin{array}{l}\text { Light red medium sandstone } \\
\text { containing conglomerates, con- } \\
\text { glomerates with small diameter } \\
\text { mainly composed of limestone } \\
\text { containing few of silica }\end{array}$ & & 3 & 20.84 \\
\hline & TTQ-S5 & $\begin{array}{l}\text { Light red medium sandstone } \\
\text { containing lots of conglomerates } \\
\text { with diameter of } 0.2-3 \mathrm{~cm} \text {, and } \\
\text { conglomerates mainly composed } \\
\text { of feldspar, limestone and sili- } \\
\text { ceous minerals }\end{array}$ & & 4 & 23.12 \\
\hline & TTQ-L2 & $\begin{array}{l}\text { Grey red conglomerates with } \\
\text { diameter of } 0.1-1 \mathrm{~cm} \text {, and con- } \\
\text { glomerates mainly composed of } \\
\text { limestone containing feldspar } \\
\text { and siliceous rock fragments }\end{array}$ & \multirow[b]{2}{*}{39.91} & 2 & 31.98 \\
\hline & TTQ-L4 & $\begin{array}{l}\text { Grey red conglomerates with } \\
\text { small diameter of } 1-5 \mathrm{~mm} \text { and } \\
\text { conglomerates mainly composed } \\
\text { of limestone containing feldspar } \\
\text { and siliceous rock fragments }\end{array}$ & & 4 & 28.73 \\
\hline \multirow{2}{*}{$\begin{array}{c}\text { Groove of } \\
\text { Hunyuan Cave, } \\
\mathrm{K}_{2} d \text { Danxia } \\
\text { Formation }\end{array}$} & HYD-S1 & $\begin{array}{l}\text { Light red sandstone containing } \\
\text { siltstone }\end{array}$ & \multirow{2}{*}{67.08} & 2 & 51.68 \\
\hline & HYD-S2 & $\begin{array}{l}\text { Light red fine-sandstone with } \\
\text { hard and homogeneous texture }\end{array}$ & & 4 & 40.90 \\
\hline
\end{tabular}


Table 4 Experimental records of ability to resist against freezing and thawing of rocks in the research sites

\begin{tabular}{|c|c|c|c|c|c|}
\hline $\begin{array}{l}\text { Formation of sampling } \\
\text { sites and developmental } \\
\text { geomorphologic position }\end{array}$ & $\begin{array}{l}\text { Lithology } \\
\text { and number }\end{array}$ & $\begin{array}{l}\text { Freezing } \\
\text { temperature } \\
\quad\left({ }^{\circ} \mathrm{C}\right)\end{array}$ & $\begin{array}{c}\text { Thawing } \\
\text { temperature } \\
\left({ }^{\circ} \mathrm{C}\right)\end{array}$ & $\begin{array}{l}\text { Destructive load } \\
\text { after freezing and } \\
\text { thawing }(K N)\end{array}$ & $\begin{array}{l}\text { Strength to an- } \\
\text { ti-pressure after } \\
\text { freezing and } \\
\text { thawing }(M P a)\end{array}$ \\
\hline \multirow{7}{*}{$\begin{array}{l}\text { Through cave of } \\
\text { Fengcheyan, } \mathrm{K}_{2} d \\
\text { Danxia Formation }\end{array}$} & FCY-S1D & \multirow{7}{*}{-20} & \multirow{7}{*}{20} & 8.00 & 4.22 \\
\hline & FCY-S2D & & & 26.50 & 12.21 \\
\hline & FCY-S3D & & & 13.50 & 6.94 \\
\hline & FCY-S8D & & & 118.00 & 48.72 \\
\hline & FCY-L2D & & & 52.80 & 22.16 \\
\hline & FCY-L4D & & & 104.50 & 42.89 \\
\hline & FCY-L6D & & & 72.40 & 29.69 \\
\hline \multirow{9}{*}{$\begin{array}{l}\text { Yangyuanshi stone pillar, } \\
\mathrm{K}_{2} d \text { Danxia Formation }\end{array}$} & YYS-S6A & \multirow{9}{*}{-20} & \multirow{9}{*}{20} & 91.50 & 37.83 \\
\hline & YYS-S6B & & & 102.00 & 41.82 \\
\hline & YYS-S7 & & & 84.00 & 34.49 \\
\hline & YYS-S5D & & & 40.50 & 16.89 \\
\hline & YYS-S7D & & & 86.50 & 35.63 \\
\hline & YYS-L3D & & & 132.00 & 55.86 \\
\hline & YYS-L8D & & & 146.20 & 59.60 \\
\hline & YYS-L9D & & & 150.00 & 61.07 \\
\hline & YYS-L10D & & & 149.20 & 61.10 \\
\hline \multirow{5}{*}{$\begin{array}{c}\text { Jinshiyan groove, } \mathrm{K}_{2} d \\
\text { Danxia Formation }\end{array}$} & JSY-S4D & \multirow{5}{*}{-20} & \multirow{5}{*}{20} & 122.20 & 50.39 \\
\hline & JSY-S5D & & & 123.00 & 49.89 \\
\hline & JSY-S6D & & & 165.00 & 72.12 \\
\hline & JSY-L5D & & & 85.00 & 35.77 \\
\hline & JSY-L7D & & & 101.00 & 42.33 \\
\hline \multirow{9}{*}{$\begin{array}{l}\text { Groove next to Tongtai } \\
\text { bridge, } \mathrm{K}_{2} d \text { Danxia } \\
\text { Formation }\end{array}$} & TTQ-S1 & \multirow{9}{*}{-20} & \multirow{9}{*}{20} & 68.50 & 28.70 \\
\hline & TTQ-S1D & & & 52.00 & 21.78 \\
\hline & TTQ-S3D & & & 43.00 & 17.78 \\
\hline & TTQ-S4D & & & 55.30 & 22.77 \\
\hline & TTQ-L3 & & & 64.50 & 26.75 \\
\hline & TTQ-L3D & & & 56.00 & 23.30 \\
\hline & TTQ-L4D & & & 69.80 & 28.90 \\
\hline & TTQ-L7D & & & 87.50 & 36.11 \\
\hline & TTQ-L8D & & & 120.20 & 49.76 \\
\hline $\begin{array}{l}\text { Groove of Hunyuan Cave, } \\
\mathrm{K}_{2} d \text { Danxia Formation }\end{array}$ & HYD-S3 & -20 & 20 & 151.80 & 61.06 \\
\hline
\end{tabular}


Table 5 X-Ray fluorescence spectrum (XRF) analysis results of element contents of white spot samples from Changba Formation $\left(\mathrm{K}_{1} c\right)$

\begin{tabular}{|c|c|c|c|c|c|c|c|c|c|c|c|}
\hline Sample No. /Element & $\mathrm{SiO}_{2}$ & $\mathrm{Al}_{2} \mathrm{O}_{3}$ & $\mathrm{CaO}$ & $\mathrm{K}_{2} \mathrm{O}$ & $\mathrm{MgO}$ & $\mathrm{Fe}_{2} \mathrm{O}_{3}$ & $\mathrm{Na}_{2} \mathrm{O}$ & $\mathrm{TiO}_{2}$ & $\mathrm{BaO}$ & $\mathrm{MnO}$ & $\mathrm{Rb}_{2} \mathrm{O}$ \\
\hline White spot B-1 & 65.0 & 12.7 & 10.3 & 3.06 & 1.20 & 0.88 & 0.52 & 0.24 & 0.106 & 0.098 & 0.029 \\
\hline White spot B-2 & 64.2 & 12.6 & 11.2 & 2.91 & 1.23 & 0.87 & 0.54 & 0.29 & 0.096 & 0.090 & 0.030 \\
\hline $\begin{array}{l}\text { Red sandstone around } \\
\text { white spot H-1 }\end{array}$ & 64.2 & 12.6 & 11.1 & 2.97 & 1.32 & 1.09 & 0.37 & 0.23 & 0.054 & 0.079 & 0.027 \\
\hline $\begin{array}{l}\text { Red sandstone around } \\
\text { white spot H-2 }\end{array}$ & 64.3 & 12.7 & 10.4 & 3.10 & 1.21 & 1.12 & 0.52 & 0.21 & 0.052 & 0.057 & 0.036 \\
\hline Sample No. /Element & $\mathrm{ZrO}_{2}$ & $\mathrm{SrO}$ & $\mathrm{V}_{2} \mathrm{O}_{5}$ & LOI & $\mathrm{Cr}_{2} \mathrm{O}_{3}$ & $\mathrm{ZnO}$ & $\mathrm{NiO}$ & $\mathrm{SO}_{3}$ & $\mathrm{Rb} ※$ & Sr※ & $\mathrm{Ti} ※$ \\
\hline White spot B-1 & 0.024 & 0.012 & 0.0012 & 5.73 & $\longrightarrow$ & $\longrightarrow$ & $\longrightarrow$ & 0.106 & 131 & 58 & 1219 \\
\hline White spot B-2 & 0.020 & 0.010 & 0.0055 & 5.89 & 0.0074 & 0.0003 & - & 0.096 & 129 & 60 & 1377 \\
\hline $\begin{array}{l}\text { Red sandstone around } \\
\text { white spot } \mathrm{H}-1\end{array}$ & 0.019 & 0.009 & 0.0017 & 5.86 & 0.0079 & & 0.0034 & 0.054 & 135 & 59 & 1198 \\
\hline $\begin{array}{l}\text { Red sandstone around } \\
\text { white spot } \mathrm{H}-2\end{array}$ & 0.018 & 0.009 & 0.0018 & 6.21 & 0.0069 & 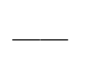 & 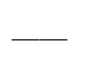 & 0.052 & 139 & 59 & 1096 \\
\hline
\end{tabular}

Note: The units of the elements marked with “※” are ppm, and the rest are \%.

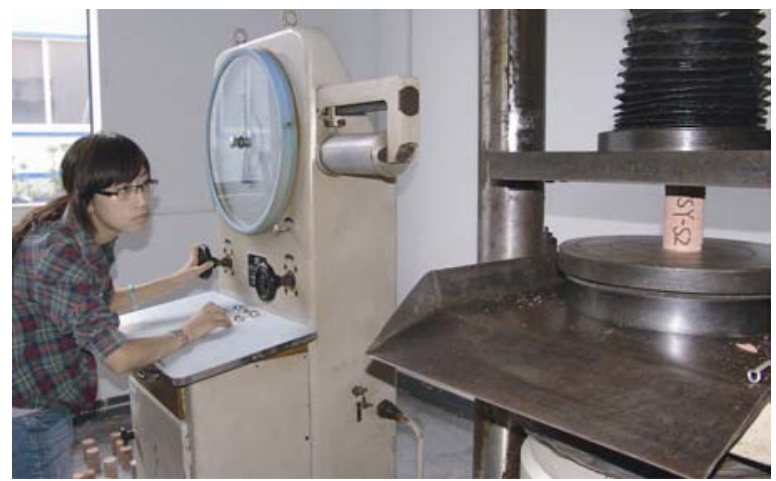

Figure 5 The YE-2000 hydraulic pressure testing machine is carrying on the experiment of the rocks to uniaxial mechanical strength

samples and 10 conglomerate samples collected at the research sites were placed in these sulfuric acid solutions with different concentrations. During a continuous monitoring observation and measurement of 25 days, the processes of erosion and changes of the test pieces were observed and measured. After having been immersed for 25 days, the test pieces were taken out and washed clearly and their outer surfaces were brushed dry so that the experiment of mechanical strength could be carried out again. Table 3 shows some records about this experiment.

The resistance against freezing and thawing experiment was carried out following Procedures of Rock Resistance against Freezing and Thawing Experiments promulgated by the National Development and Reform Commission (NDRC) of PRC (2007) and the Ministry of Transport of the PRC (2005). A total of 16 cylindrical samples of sandstones and 14 cylindrical samples of conglomerates were adopted with a ratio between height and diameter of $2: 1$. After the test pieces had been immersed in distilled water for $24 \mathrm{~h}$, the surfaces of the test pieces were brushed dry and the test pieces were weighed. They were then placed into an ice box with a temperature of $-20^{\circ} \mathrm{C}$ and were taken out $4 \mathrm{~h}$ later and placed into a water 


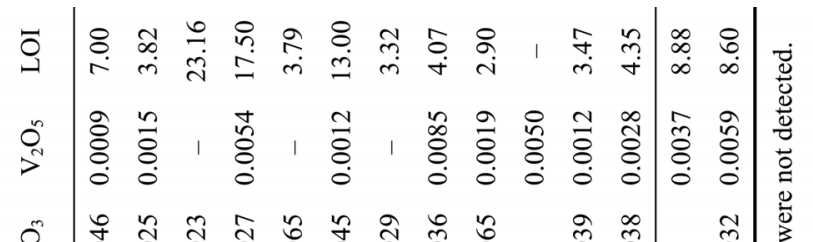

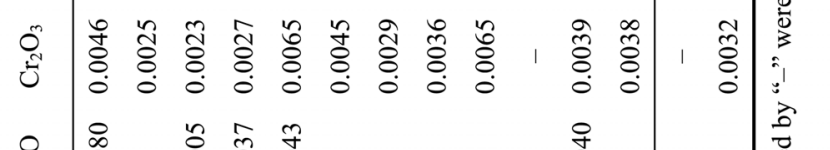

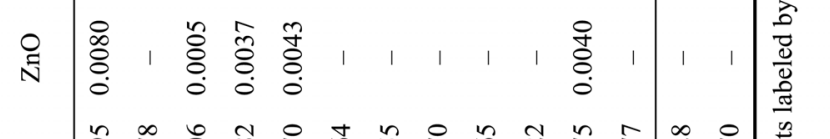

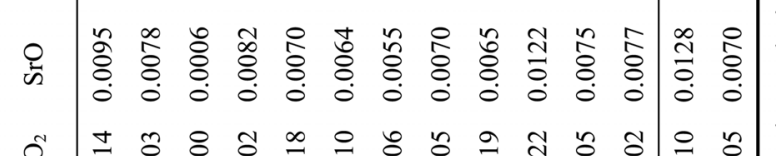

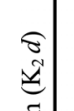

崩

㐱

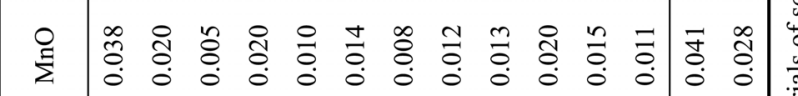

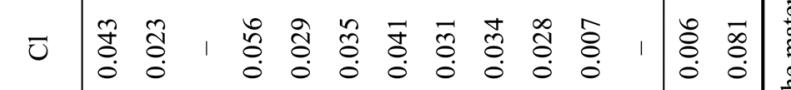

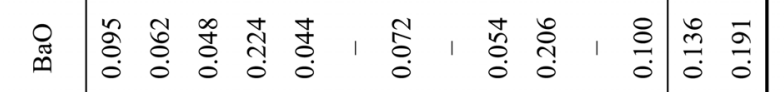

윱

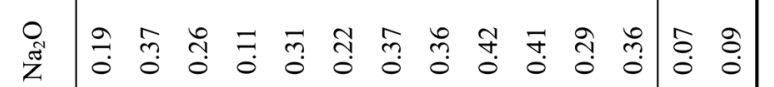

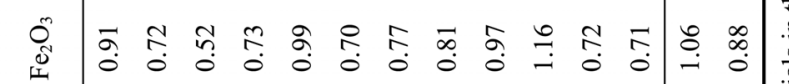

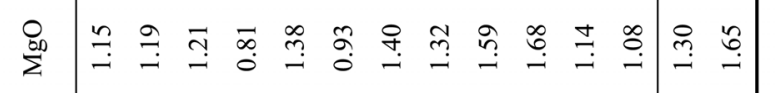

กิ

审

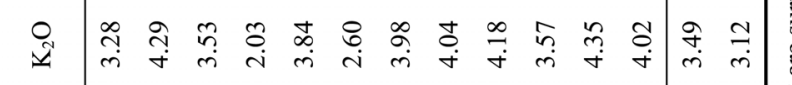

产

离

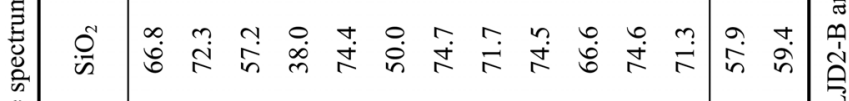

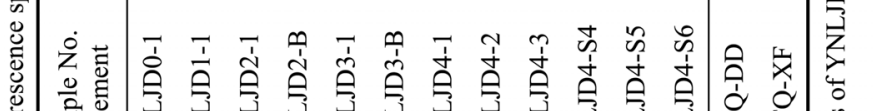


Table 8 Identification results of typical Danxia landscape rocks under a polarizing microscope

\begin{tabular}{|c|c|c|c|c|c|}
\hline $\begin{array}{l}\text { Sample } \\
\text { number }\end{array}$ & Site & $\begin{array}{l}\text { Longitude } \\
\text { and latitude }\end{array}$ & $\begin{array}{l}\text { Eleva- } \\
\text { tion }(m)\end{array}$ & Lithology & $\begin{array}{l}\text { Lithological features under the } \\
\text { polarizing microscope }\end{array}$ \\
\hline
\end{tabular}

\begin{tabular}{|c|c|c|c|c|}
\hline FCY-S3 & $\begin{array}{l}\text { Through } \\
\text { cave of } \\
\text { Feng- } \\
\text { cheyan }\end{array}$ & $\begin{array}{l}\text { N2502.645', } \\
\text { E113 }\end{array}$ & 160 & $\begin{array}{l}\text { Fine } \\
\text { sandstone }\end{array}$ \\
\hline
\end{tabular}

The diameters of most of the fragments range from 0.1 to $0.2 \mathrm{~mm}$, some could reach $0.5-0.8 \mathrm{~mm}$. The fragments are well-sorted with sub-rounded roundness and developed porosity. There is loess sand touched by hand, and the degree of cementacheyan tion is low only with ferruginous cements. Most of the fragments are quart, and feldspar, siliceous debris and ferruginous cements distributed around the fragments with membranous shape. The feldspar mainly consists of microcline without obvious pores, or the pores are very small.

The diameters of gravels are between 3-30 mm with poor sorting, the degrees of roundness are from sub-rounded to sub-angular. And conglomerates account for about $50 \%$, the filled materials

Through $\begin{array}{ll}\text { FCY-L4 } & \text { cave of } \\ \text { Feng- }\end{array}$ cheyan
$\mathrm{N} 25^{\circ} 02.645^{\prime}$, $\mathrm{E} 113^{\circ} 43.545^{\prime}$ 160
Calcareous conglomerate among gravels are medium-sand and fine-sand debris consisting of mudstone debris, fine-sand debris, limestone debris and multi-grain quartz fragments with medium-sand, fine-sand and calcareous cements as interstitial matters, which are deposited locally. And there are few of ferruginous cements distributed at the edge of the fragments with membranous shape.

\begin{tabular}{|c|c|c|c|c|}
\hline YYS-S4 & $\begin{array}{l}\text { Bottom } \\
\text { of Yan- } \\
\text { gyuanshi } \\
\text { stone } \\
\text { pillar }\end{array}$ & $\begin{array}{l}\mathrm{N}^{\circ} 5^{\circ} 02.592^{\prime}, \\
\mathrm{E} 113^{\circ} 43.901^{\prime}\end{array}$ & 139 & $\begin{array}{l}\text { Medium } \\
\text { and } \\
\text { fine-grain- } \\
\text { ed sand- } \\
\text { stone }\end{array}$ \\
\hline
\end{tabular}

The degree of roundness is poor sorting and mainly consisting of sub-angular, there are only a few of interstitial matters only with a small amount of ferruginous cements distributed around the fragments. And shale filler account for $5 \%$ with developed porosity among gravels. There are heavy minerals such as tourmaline (the content of which is less than 1\%). Feldspar accounts for $15 \%$ and the microcline could be found, there is few of siliceous rock-fragments (2\%) and mudstone fragments (5\%) without calcspar cements.

The diameters of gravels focus on 5-25 mm and its content is about $60 \%$ with the roundness from sub-rounded to sub-angular and ferruginous ce-

Bottom of Yan-

YYS-L2 gyuanshi stone pillar
$\mathrm{N} 25^{\circ} 02.592^{\prime}$, $\mathrm{E} 113^{\circ} 43.901^{\prime}$ 139
Conglomerate ments. The rest are interstitial matters (40\%) consisting of medium-sand, fine-sand and calcspar cements. The fragments are mainly composed of feldspar, multi-grain quartz debris, limestone debris and mudstone debris.

The diameters of well-sorted fragments range from 0.06 to $0.25 \mathrm{~mm}$ with medium roundness and porous cementation. The compositions are fragments $(75 \%)$, heavy minerals (tourmaline and zircon, 1\%) and cements (25\%). The fragments

Calcareous fine sandstone mainly consist of quartz, the other compositions

\begin{tabular}{|c|c|c|c|}
\hline JSY-S2 & $\begin{array}{l}\text { Jinshiyan } \\
\text { groove }\end{array}$ & $\begin{array}{l}\text { N25 } 01.710^{\prime}, \\
\mathrm{E}^{\circ} 13^{\circ} 44.248^{\prime}\end{array}$ & 307 \\
\hline
\end{tabular}
are feldspar ( $4 \%)$ and muscovite $(<1 \%)$. And the interstitial matters are calcspar cements mixed with few of pelitic strips, accounting for $25 \%$, even $30 \%$ in partial, they are white interference color with apparent apophysis. The ferruginous cements are distributed around the edge of fragments with membranous shape. 
(Continued)

\begin{tabular}{|c|c|c|c|c|c|}
\hline $\begin{array}{l}\text { Sample } \\
\text { number }\end{array}$ & Site & $\begin{array}{l}\text { Longitude } \\
\text { and latitude }\end{array}$ & $\begin{array}{l}\text { Eleva- } \\
\text { tion }(m)\end{array}$ & Lithology & $\begin{array}{l}\text { Lithological features under the } \\
\text { polarizing microscope }\end{array}$ \\
\hline
\end{tabular}

\begin{tabular}{|c|c|c|c|c|}
\hline JSY-L4 & $\begin{array}{l}\text { Jinshiyan } \\
\text { groove }\end{array}$ & $\begin{array}{l}\mathrm{N} 25^{\circ} 01.710^{\prime}, \\
\mathrm{E} 113^{\circ} 44.248^{\prime}\end{array}$ & 307 & $\begin{array}{l}\text { Conglom- } \\
\text { erate }\end{array}$ \\
\hline
\end{tabular}

$\begin{array}{lll} & & \\ & \text { Tongtai } & \\ \text { TTQ-S5 } & \begin{array}{l}\text { natural } \\ \text { bridge }\end{array} & \text { E113⒋906', } \\ & & \end{array}$

\begin{tabular}{|c|c|c|}
\hline TTQ-L8 & $\begin{array}{l}\text { Tongtai } \\
\text { natural } \\
\text { bridge }\end{array}$ & $\begin{array}{l}\mathrm{N}^{2} 5^{\circ} 02.906^{\prime}, \\
\mathrm{E} 113^{\circ} 43.696^{\prime}\end{array}$ \\
\hline
\end{tabular}
The gravels are carbonatite with calcareous cements
among gravels. There is limestone containing biological fossils, most of which are crinoids. The compositions of gravels are bioclastic microcrystalline limestone, multi-grain quartz, feldspar, fine-sand fragments and biotite phenocryst acid lava debris. The interstitial matters mainly are calcspar cements and sand. The ferruginous cements are distributed around the edge of fragments.

Calcare- The diameters of most of fragments range from 0.2 ous me- to $0.4 \mathrm{~mm}$. The compositions are feldspar (5\%), dium and limestone debris (3\%), siliceous rock debris fine-grain- $\quad(2 \%-3 \%)$, and cements $(25 \%)$. The fragments are ed sand- mainly composed of feldspar; ferruginous cements stone are distributed around the edge of the fragments.

The content of gravels accounts for $65 \%$ with the diameters ranging from 3 to $10 \mathrm{~mm}$, and main $\begin{array}{ll}\text { Calcare- } & \text { roundness of sub-angular. The compositions of } \\ \text { gravels are limestone, multi-grain quartz and fine }\end{array}$ ous con- sand. The length-width ratios of gravels are big and glomerate could reach $8 \mathrm{~mm} \times 1 \mathrm{~mm}$, based on this, the gravels are deposited locally. The interstitial matters account for $35 \%$, and the volcanic rock debris with porphyritic texture could be occasionally observed.

The roundness is from sub-rounded to sub-angular. Calcare- The calcspar cements account for $35 \%-40 \%$, the ous me- content of which is the biggest in all samples. The dium and fragments account for $60 \%-65 \%$ including feldspar fine-grain- $\quad(3 \%-4 \%)$, tourmaline, ferric oxide, and few of ed sand- siliceous rock debris and clay. And few of ferrugistone nous cements are distributed around the edge of fragments.

\begin{tabular}{|c|c|c|c|c|}
\hline HYD-S2 & $\begin{array}{l}\text { Hunyuan } \\
\text { Cave }\end{array}$ & $\begin{array}{l}\mathrm{N}^{\circ} 5^{\circ} 02.900^{\prime}, \\
\mathrm{E} 113^{\circ} 43.717^{\prime}\end{array}$ & 350 & $\begin{array}{l}\text { dium and } \\
\text { fine-grain- } \\
\text { ed sand- } \\
\text { stone }\end{array}$ \\
\hline HYD-N2 & $\begin{array}{l}\text { Hunyuan } \\
\text { Cave }\end{array}$ & $\begin{array}{l}\mathrm{N}^{2} 5^{\circ} 02.900^{\prime}, \\
\mathrm{E} 113^{\circ} 43.717^{\prime}\end{array}$ & 350 & Mudstone \\
\hline
\end{tabular}

The main compositions are tiny hair-like or scalelike clay minerals, the rest are few of maroon ferric oxide, and few of calcite filled in cracks and pores, and fine sand accounting for $2 \%-5 \%$.

The diameters range from 0.15 to $1.2 \mathrm{~mm}$ with unequigranular texture, the main roundness of coarse particles is sub-rounded, and the medium particles are from sub-rounded to sub-angular. The $\begin{array}{ll}\text { Me- } & \text { maturity of component is poor, and the fragments } \\ \text { dium-thic } & \text { mainly consist of quartz, feldspar, limestone debris. }\end{array}$ dium-thic The quartz is mainly composed of single-crystal $\mathrm{k}$ grained quartz and few of multi-grain quartz $(1 \mathrm{~mm})$, and sandstone feldspar is mainly composed of microcline, and few of acid plagioclase and perthite. The compositions are feldspar (20\%), mudstone debris (2\%), calcareous cements (5\%), fine sand and a little clay, in which the total content of cements is about $20 \%$.

The diameters range from 0.15 to $0.4 \mathrm{~mm}$ with $\begin{array}{ll}\text { Medium } & \text { roundness from sub-rounded to sub-angular, and the } \\ \text { and } & \text { fragments consist of quartz, feldspar and siliceous }\end{array}$ and fine-grain- rock debris with medium sorting. And the calcarefine-grain-
ed sanded sand- mainly consist of calcareous cements accounting for $30 \%$. Ferruginous cements are distributed around the edge of fragments. 

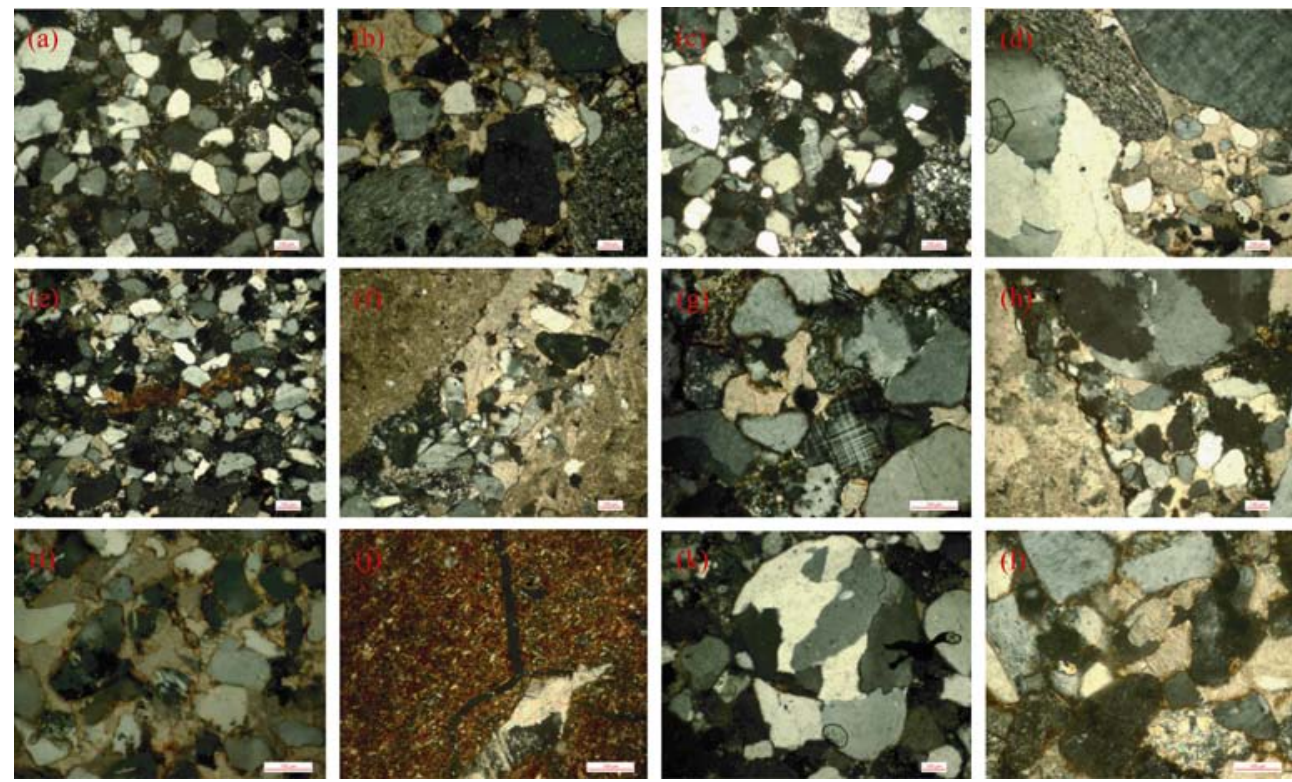

Figure 6 Identification photographs of part of the lithology specimens under a polarizing microscope (Orthogonal×10). (a) Sandstone (FCY-S3) of Fengcheyan through cave; (b) Conglomerate (FCY-L4) of Fengcheyan through cave; (c) Sandstone (YYS-S4) of Yangyuanshi stone pillar; (d) Conglomerate (YYS-L2) of Yangyuanshi stone pillar; (e) Sandstone (JSY-S2) of Jinshiyan groove; (f) Conglomerate (JSY-L4) of Jinshiyan groove; (g) Sandstone (TTQ-S5) of groove next to Tongtai natural bridge; (H) Conglomerate (TTQ-L8) of groove next to Tongtai natural bridge; (i) Sandstone (HYD-S2) of Hunyuan Cave; (j) Mudstone (HYD-N2) of Hunyuan Cave; (k) Sandstone (YNLJD4-1) of Yunvlanjiang honeycomb cave; (l) Sandstone (TTQ-FW) of Tongtai natural bridge

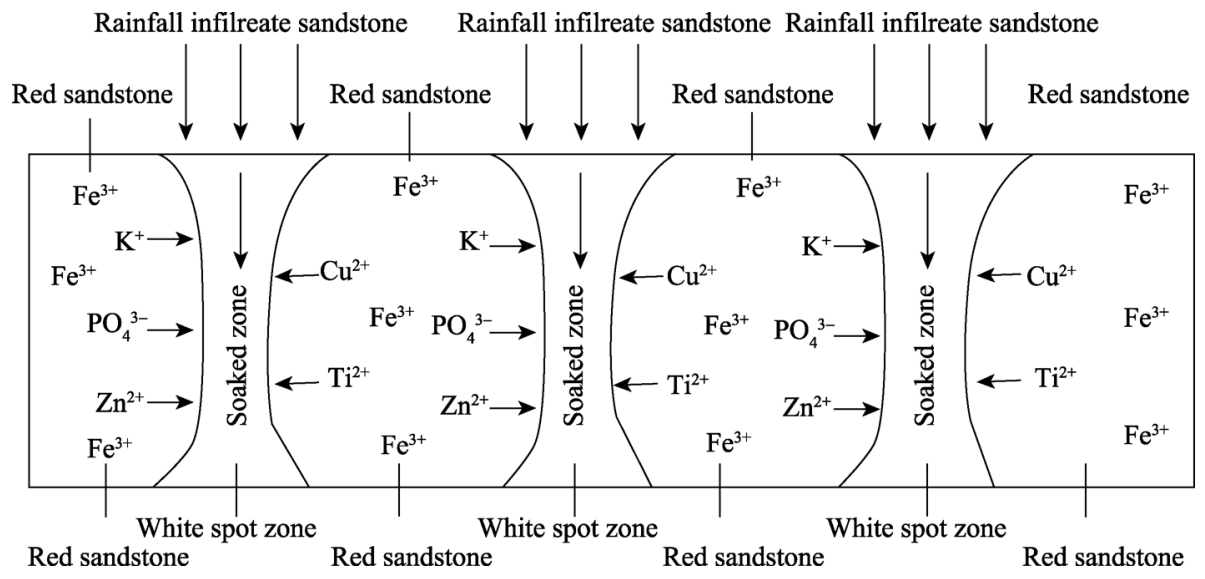

Figure 7 Sketch map of geomophogensis of white spot in Danxia landform

trough with a constant temperature of $20^{\circ} \mathrm{C}$, and $4 \mathrm{~h}$ later they were placed again in the ice box with a temperature of $-20^{\circ} \mathrm{C}$. This process was repeated 25 times and after a continuous observation of 4 days, the test pieces were taken out so that the experiment could be carried out again. Table 4 shows some records of experiment.

$\mathrm{X}$-Ray fluorescence spectroscopy analysis (XRF) was performed at the Institute of Regional Environmental Evolution (IREE) and the Center of Modern Analysis (CMA), Nanjing University. Totally, 4 white spot samples from Changba Formation rock of Yamayan, 12 honeycomb cave samples from Yunvlanjiang Cave, and 2 squama stone samples from the 

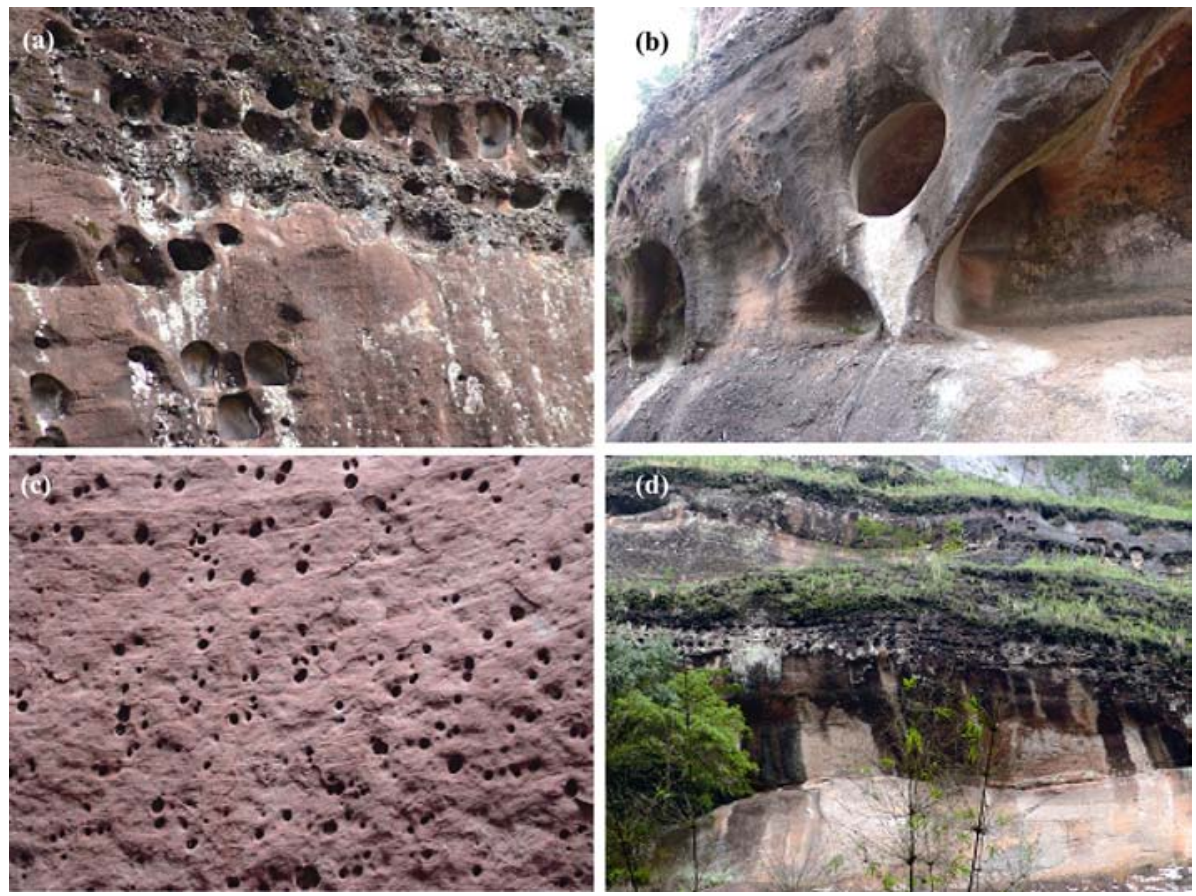

Figure 8 The features of the Honeycomb caves and small through caves at Mt. Danxiashan. (a) Honeycomb caves on precipice of Zhanglao Peak; (b) Small through caves of Mengjueguan near the Jinshiyan groove; (c) Small holes on palisades of Bazhai Tor; (d) Honeycomb caves on precipice near the Jinshiyan groove

upper wall of the groove near Tongtai natural bridge were preprocessed at IREE. $50 \mathrm{~g}$ of each dry rock sample was ground to fine powder and sieved through 200-mesh screen, then sent to CMA in which the powder sample weighing around 5-6 g was put into a $35 \mathrm{~mm}$ diameter plastic cup on a flat mould and a pressure of 30 tons was applied for molding it into a flat, crackless sample disc with a thickness of 2-4 mm. The element content of the rock samples was then measured by a Switzerland-made ARL-9800 X-Ray fluorescence spectrometer and were represented in the form of oxide percentage (Tables 5 and 6).

Inductive coupling plasma spectra mass spectroscopy analysis (ICP-MS) was also performed at CMA, Nanjing University, and the instrument used was Optima 5300 DV plasma spectrum mass spectrometer manufactured by American PE Company. Four white spot samples extracted from Changba Formation rock of Yamayan was grounded into powder and sieved through 200-mesh screen. Samples with a proper quantity were carefully put into PTFE beakers and heated with hydrochloric acid, nitric acid, hydrofluoric acid, and high chlorine acid for dissolution. After the solution drying out, the residues were extracted with hydrochloric acid. Eventually, the element contents of the samples were measured by using the ICP-MS and the results were shown in Table 7.

To examine the lithological characteristics of rocks, a total of 12 samples were collected in the study sites. They were first ground into slices in the State Key Laboratory for Mineral Research, School of Earth Sciences and Engineering, Nanjing University, and the identification of lithology was then carried out under a Nikon ECLIPSE LV100 POL polarizing microscope with the help of Associate Professor KONG Qingyou. Table 8 and Figure 6 show the records and photos of the identifications of some samples under a polarizing microscope. 


\section{Results and discussion}

Mechanical (compressive) experiments were performed on 40 rock samples collected from the Fengcheyan through cave, the base of Yangyuanshi stone pillar, the grooves near Tongtai bridge, the grooves of Jinshiyan Crag, and the grooves of Hunyuan Cave. The results showed that the average dry uniaxial mechanical strength of sandstone in the Fengcheyan through cave is only $10.77 \mathrm{MPa}$ which is much weaker than that of Yangyuanshi stone pillar (39.86 MPa), the grooves near Tongtai bridge (29.28 MPa), as well as the grooves of Jinshiyan Crag (59.65 MPa). The average mechanical (compressive) strength of Yangyuanshi conglomerate is $63.78 \mathrm{MPa}$, which is greater than that of all other landscape sites. These results suggest that the Fengcheyan through cave developed at the sandstone layer with the lowest anti-compressive strength, while the Yangyuanshi stone pillar developed at the sandy conglomerate layer with fairly high anti-compressive strength.

The average dry and wet uniaxial mechanical strengths are 43.51 MPa and 35.47 MPa for conglomerate and 41.70 MPa and 30.30 MPa for sandstone, respectively. We can see that dry uniaxial mechanical strength is higher than wet uniaxial mechanical strength for both conglomerate and sandstone, which suggests Danxia stratum is more susceptible to erosion and weathering processes in rainy seasons or under fluvial conditions.

The testing core samples declined in compressive strength after being immersed into diluted sulphuric acid solution. The compressive strength of the sandstone in Fengchenyan through cave decreased from 10.77 MPa to only 3.71 MPa; and the Yangyuanshi sandstone, from 39.86 MPa to 26.52 MPa; the Jinshiyan Crag groove, from 59.65 MPa to 53.57 MPa. This suggests that erosion on Danxia stratum could be accelerated if acid rains were formed by the volcanic eruptions in the Mesozoic Cretaceous period.

After the testing core samples of sandstone having experienced freezing and thawing cycles in the lab, their dry and wet uniaxial mechanical strength declined as well. The average dry uniaxial mechanical strength of sandstone declined from 41.70 $\mathrm{MPa}$ and to 36.15 $\mathrm{MPa}$, and the average wet uniaxial mechanical strength, from $30.30 \mathrm{MPa}$ to $23.32 \mathrm{MPa}$. This suggests that the climate fluctuation cycles during the Quaternary glacial periods and interglacial periods might have also had influence on the resistance of rocks against weathering in Mt. Danxiashan.

\subsection{Genesis of white spot}

The white spots are grey stains frequently seen on the surfaces of red sandstone in Mt. Danxiashan. They are different in size, mostly appearing in round and oval shapes with diameters around 2-10 cm. These kind of white spots were also found inside rocks after the rock samples were smashed during the lab tests. During the on-the-spot investigations, we speculated that the white spots were caused by the enrichment of calcium in rocks, but the lab test results indicated that the calcium content of the white spot samples is not significantly higher than the bedrock samples (Tables 5 and 7). From ICP-MS and XRF analysis, it can be seen that calcium content of red bedrock samples is even higher than that of white spot samples. Therefore, the formation of white spots is not due to the calcium enrichment.

ICP-MS and XRF analysis showed that the contents of two other ions, $\mathrm{Fe}^{3+}$ and $\mathrm{SO}_{4}{ }^{2-}$, are very different between white spots and bedrocks. The content of $\mathrm{Fe}^{3+}$ in the red bedrock is 
higher than that in white spots, while the content of $\mathrm{SO}_{4}{ }^{2-}$ in white spots is higher than that in the bedrock, which validated the early finding by Chen (1941). While ferric iron $\left(\mathrm{Fe}^{3+}\right)$ in the red bedrock was reduced into ferrous iron $\left(\mathrm{Fe}^{2+}\right)$, the original red color faded away, turning into white spot, and $\mathrm{SO}_{4}{ }^{2-}$ might have been accumulated in white spots during the reduction reaction. Polarizing microscope identifications indicated that the sediment compositions of white spots and their surrounding red sandstones are very similar in granularity, psephicity and sedimentary structure, which suggests that white spots must have been formed under the secondary-reaction conditions after the sandstones were formed. As the red sandstones in Danxia landform were a permeable medium, rain water could infiltrate into the rock to develop many cylindrical infiltration zones (Figure 7). As a result, the ions such as $\mathrm{K}^{+}, \mathrm{Zn}^{2+}, \mathrm{Ti}^{2+}, \mathrm{Cu}^{2+}$ and $\mathrm{PO}_{4}{ }^{3-}$ in the sandstone were prone to flowing towards and being enriched in the infiltration zones, while the red $\mathrm{Fe}^{3+}$ was reduced to $\mathrm{Fe}^{2+}$ and leached away, resulting in bleaching. In contrast, the dry portions of the sandstones were in a relatively oxidized environment and the red $\mathrm{Fe}^{3+}$ was prone to being enriched. Eventually, the white spots were created in the infiltration zones and surrounded by the red sandstones at which oxidation reactions took place.

\subsection{Genesis of honeycomb cave, small through cave and natural bridge}

A large number of honeycomb caves and small through caves are spread throughout Jinshiyan, Mengjueguan and Bazhai areas in the Mt. Danxiashan region (Figure 8). Analysis of the honeycomb cave samples collected from Yunvlanjiang Cave indicates that the chemical compositions of the sandstone and its bedrock where honeycomb caves developed are similar (Table 6), which suggests that the development of honeycomb caves has nothing to do with the chemical difference in lithology. On the basis of the above discussion on the formation of white spots and the analysis on the element content and structure of honeycomb caves in Yunvlanjiang Cave, we proposed that the development of small through caves and honeycomb caves on precipice walls might have been related to the infiltration zones (Figures 9 and 10). When water moving vertically through the cylindrical infiltration zones in sandstone rocks and coming across the aquiclude layer at the bottom, it would change directions and move laterally. If the laterally moving water seeped out of the free face of a precipice, the mineral substances and active ions such as $\mathrm{K}^{+}, \mathrm{Zn}^{2+}, \mathrm{Ti}^{2+}, \mathrm{Cu}^{2+}$ and $\mathrm{PO}_{4}{ }^{3-}$ would be washed away as well. As a result, honeycomb caves eventually took shape (Figure 9). If water transfused and overflew through both sides of the same rock precipice, small through caves could gradually be developed as mineral substances in the rock were washed away at the both sides of the precipice (Figure 10). While as the area without infiltration was in relatively dry oxidation zone, the compositions of red sandstone containing large

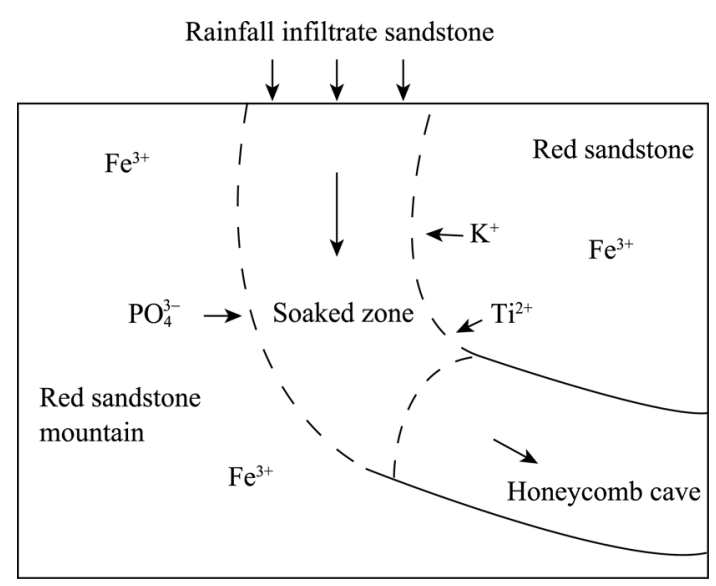

Figure 9 Sketch map of geomophogensis of honeycomb caves on precipice near the Jinshiyan groove 
amount of $\mathrm{Fe}^{3+}$ remained, and this is well proved by the white spots around cave edge and at the exit (Figure 8).

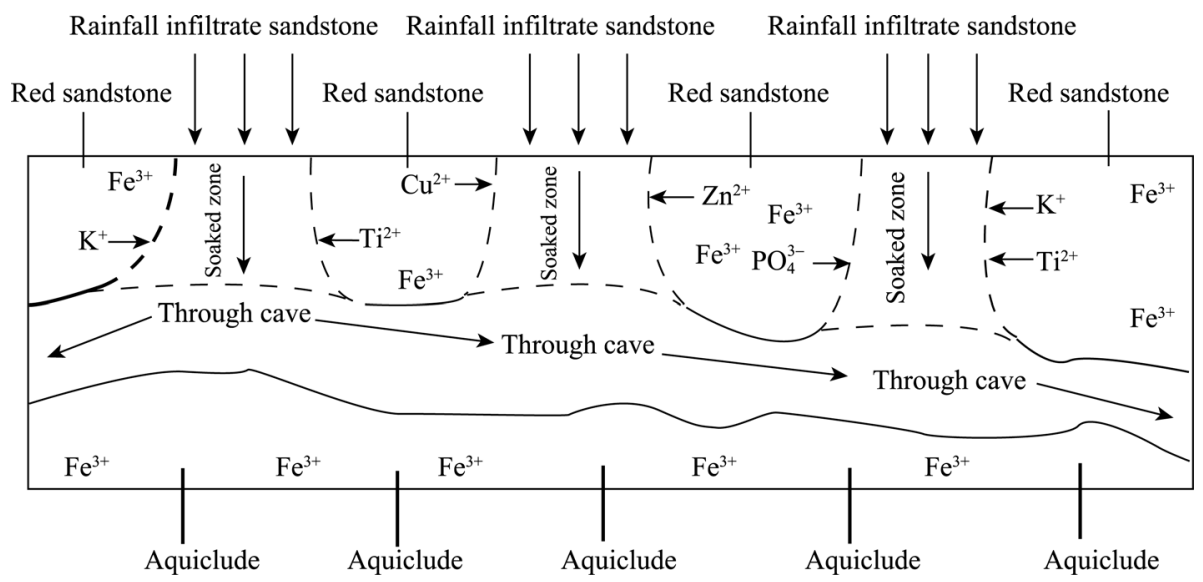

Figure 10 Sketch map of geomophogensis of small through caves of Mengjueguan near the Jinshiyan groove

The results of compressive experiments on the samples of the Tongtai natural bridge are shown in Tables 2-4. It can be seen that the dry and wet compressive strength of sandstone and conglomerate in Tongtai natural bridge is significantly weaker than that in the Yangyuanshi and Jinshiyan areas, which suggests that the bedrocks in Tongtai bridge are softer than those in the Yangyuanshi and Jinshiyan areas. But the bedrocks in the three sites show the following similar characteristics: the dry compressive strength is higher than the wet compressive strength; the compressive strength of sandstone is weaker than that of conglomerate; and sandstone were seriously affected by rainfall and thus prone to erosion. At the both sides of Tongtai bridge, a set of large joints, with cracks of $40-60 \mathrm{~cm}$ in width, are aligned NW350 ${ }^{\circ}$ and parallel to the bridge. The formation of Tongtai natural bridge was on one hand controlled by the joints, and on the other hand, was related to the dissolution of rocks. The upper part of Tongtai bridge composed of conglomerate with good permeability, which enabled rainwater to infiltrate readily during rainfall seasons and to wash away more soluble substances such as $\mathrm{Ca}^{2+}$ and $\mathrm{K}^{+}$ions of sandstone at the bottom. Gradually, through caves developed, and expanded by dissolution and collapses. The suspension of the upper stratum above the through cave is what we see today, the natural bridge.

\subsection{Genesis of horizontal groove}

The testing results of the core samples taken from the three large flat grooves in Mt. Danxiashan are listed in Tables 2-4. In Jinshiyan, the dry compressive strength of conglomerate and sandstone is $53.41 \mathrm{MPa}$ vs. $34.36 \mathrm{MPa}$; the compressive strength of conglomerate and sandstone after acid immersion is $46.4 \mathrm{MPa}$ vs. $42.93 \mathrm{MPa}$. In the Tongtai natural bridge, the dry compressive strength of the groove and sandstone is $31.98 \mathrm{MPa}$ vs. 23.42 $\mathrm{MPa}$; the compressive strength of conglomerate and sandstone after acid immersion is $52.38 \mathrm{MPa}$ vs. 38.02 MPa. In Hunyuan Cave, the dry compressive strength of groove and sandstone is 28.73 MPa vs. 23.12 MPa; the compressive strength of conglomerate and sandstone after acid immersion is $28.70 \mathrm{MPa}$ vs. $23 \mathrm{MPa}$. The experiments on the resistance of rocks against 
freezing-thawing also indicate that the compressive strength of conglomerate is greater than that of sandstone. Under the climatic conditions of abundant rainfall in Mt. Danxianshan, the thick and stronger conglomerate layer above the grooves is less erodible, but more prone to water infiltration due to its composition of large particles and the dense fissures. When infiltration water entered the weaker sandstone layer, more severe erosion took place and eventually a flat groove developed.

However, the previous studies of horizontal grooves in Danxia landform conducted by our research team (Ma et al., 2006; Ouyang et al., 2009; Zhu et al., 2010) indicated that the lithologic difference of sandstone and conglomerate was not the solo reason for the formation of grooves. From the perspective of fluvial geomorphology and tectonic uplift, the development of the large horizontal grooves of Zhanglao Peak, Sengmao Peak, Chahu Peak and Bazhai Tor might be also closely related to the lateral erosion caused by flow circulations of the Jinjiang River and the regional tectonic uplifts (Charlton, 2008). The lateral erosion of river flows during the stable period alternating with the tectonic uplifts led to the development of more than ten layers of grooves in the past. The length of a horizontal groove is therefore determined by the river bend radius. Currently, the Jinjiang River winds through Danxia Valley and the Fuyinxia groove in Zhanglao Peak is the evidence left behind by the lateral erosion of river flows and the tectonic uplifts. Thus, the large Danxia grooves can also reveal the history of the development of the Jinjiang river channel.

\subsection{Genesis of large through cave of Fengcheyan}

The Fengcheyan Cave is a typical large through cave in Mt. Danxiashan. We found that the surrounding bedrock of this cave is mainly sandstone, and conglomerate layers are occasionally sandwiched by sandstone layers. Also, at the bottom of the cave, there is a fine, less permeable sandstone layer, underlying which is a thick conglomerate layer.

As aforementioned, compressive strength of conglomerate is higher than that of sandstone; the sandstone rock was weakened greatly by water saturation, but the conglomerate rock, was only slightly. The experiments also show that the compressive strength of sandstone is 27.36 MPa after being etched with a sulfuric acid solution $(\mathrm{pH}=4)$, and is only $3.71 \mathrm{MPa}$ $(\mathrm{pH}=2)$. However, the compressive strength of conglomerate is $22.55 \mathrm{MPa}$ after being immersed in a sulfuric acid solution $(\mathrm{pH}=4)$, and is $27.69 \mathrm{MPa}(\mathrm{pH}=2)$, indicating the effect of acidity on the compressive strength of conglomerate is very limited. We observed that the sandstone was peeling off in freezing and thawing cycles. Identifications under a polarizing microscope show that the grains in sandstone are weakly bonded together. All of these suggest that the formation of the Fengcheyan through cave is related to the particularly weak sandstone, and the lithological contrast between sandstone and conglomerate becomes more profound under the conditions of freezing-thaw, water-saturation, and the presence of acid solution.

\subsection{Genesis of stone pillar of Yangyuanshi}

The experimental results of the drilling cores from Yangyuanshi in Mt. Danxiashan (Figures 2-4) show that the average compressive strengths of conglomerate and sandstone are 51.83 MPa and 32.10 MPa, respectively; the compressive strengths of conglomerate and sandstone after acid immersion are 58.43 MPa and 24.61 MPa; the compressive strengths of conglom- 
erate and sandstone after freezing and thawing are 63.78 MPa and $37.91 \mathrm{MPa}$. Identifications of the rock samples under a polarizing microscope show that both calcite and ferruginous cements that tend to bond grains together strongly are present in conglomerate, while none of the above two in sandstone. Such lithological differences, together with two sets of vertical joints $\left(188^{\circ} \mathrm{SW}\right.$ and $\left.278^{\circ} \mathrm{NW}\right)$ developed between Yangyuanshi stone pillar and Yangyuanshan Peak seems to be responsible for the development of independent stone pillar during the tectonic uplifting periods (Figure 2c).

\subsection{Genesis of squama stone}

The field investigation indicates that the squama stone is located in a long, arcuate zone of joints within a sandstone layer. Underneath squama stone, there is fine sandstone of high density, acting as an aquiclude for the above sandstone layer containing squama stone. The annual precipitation in Mt. Danxiashan amounts to $1700 \mathrm{~mm}$ or so. The surface precipitation may infiltrate through conglomerate and sandstone. When the infiltration flows are impeded by dense rock strata, they will seep out from cracks of sandstone and joints at bottom.

Identification under a polarizing microscope and X-ray fluorescence spectrum analysis (Tables 6 and 8) of squama stone samples collected from Yunvlanjiang Cave and the upper wall of the groove near Tongtai natural bridge indicated that the squama stones contain a much higher content of calcium materials than the bedrock. The CaO content of two squama stone samples collected from Yunvlanjiang Cave is $30.1 \%$ and $22.2 \%$, respectively, while the $\mathrm{CaO}$ content of the two bedrock samples is only $0.72 \%$ and $1.24 \%$; the calcium content of squama stone in the groove near Tongtai bridge is as high as $30 \%$ as well. The contrast of calcium content between squama stone and bedrock suggests that squama stone is formed due to the enrichment of calcium caused by infiltrating water along the grids. When the water dissolved with calcium seeped out and contacted with air, the grid-shaped squama stone can be slowly developed by recrystallization (Figure 2g). The surface of some squama stones is green (Figure 2g) because it is humid in the caves, and microorganisms like green algae are easy to grow on the stone surfaces (Huang, 2010).

\section{Summary and conclusions}

The formation of Danxia landform is too slow for us to observe in our life time and the climate conditions in which the Danxia landscapes developed are significantly different from present. Thus, this study adopted experimental approaches to examine the lithological and paleoclimatic control on the formation of various landscape morphologies in the Mt. Danxiashan, South China. Through the comprehensive experimental analyses aided with field investigations, we can derive the following conclusions:

(1) The uniaxial mechanical strengths of conglomerates from all the research sites of the Danxia landscape were ranked from the highest to the lowest as follows: Yangyuanshi independent stone pillar (59.61 MPa), $\rightarrow$ groove near Tongtai natural bridge (45.47 MPa) $\rightarrow$ Jinshiyan groove $(41.54 \mathrm{MPa}) \rightarrow$ through cave of Fengcheyan $(41.14 \mathrm{MPa})$. All the uniaxial mechanical strengths of sandstones were arranged from the largest to the smallest as follows: groove of Hunyuan Cave (69.13 MPa) $\rightarrow$ Jinshiyan groove $(62.46 \mathrm{MPa}) \rightarrow$ Yangyuanshi stone pillar $(49.30 \mathrm{MPa}) \rightarrow$ through cave of Fengcheyan $(11.80 \mathrm{MPa})$. All the uniaxial mechanical 
strengths of conglomerate with resistance against freezing and thawing were arranged from the highest to the lowest as follows: Yangyuanshi stone pillar (61.10 MPa) $\rightarrow$ groove near Tongtai bridge $(49.76 \mathrm{MPa}) \rightarrow$ through cave of Fengcheyan $(42.89 \mathrm{MPa}) \rightarrow$ Jinshiyan groove (42.33 MPa). All the uniaxial mechanical strengths of sandstones with resistance against freezing and thawing were arranged from the highest to the lowest as follows: Jinshiyan groove $(72.12 \mathrm{MPa}) \rightarrow$ groove of Hunyuan Cave $(61.06 \mathrm{MPa}) \rightarrow$ through cave of Fengcheyan $(48.72 \mathrm{MPa}) \rightarrow$ Yangyuanshi stone pillar $(41.82 \mathrm{MPa}) \rightarrow$ groove near Tongtai bridge (28.70 $\mathrm{MPa}$ ). As proved by the experiments, in the same area of the Danxia landscape, the dry uniaxial mechanical strengths of both sandstones and conglomerates are universally higher than the wet uniaxial mechanical strengths, which indicates that Danxia rocks tend to crack and collapse more easily in rainy and water-saturated seasons. The conglomerate of Yangyuanshi stone pillar has the highest compressive strength and resistance against freezing and thawing actions among all the research sites whereas the conglomerate and sandstone of the Fengcheyan through cave have the lowest compressive strength and resistance against freezing and thawing actions among all the research sites. Certainly, roles of microclimate and lithologic differences in the development of different Danxia landscapes should be researched further.

(2) As also indicated by the experiments, the sandstones and conglomerates in the research sites of the Danxia landscape are highly sensitive to the action of acid erosion: after being immersed in the dilute sulfuric acid solution for 25 days, the compressive strengths of almost all the rock specimens collected in the sites of landscape morphologies decreased. For example, the compressive strength of the sandstones in the groove of Hunyuan Cave was 67.08 MPa before being immersed in acid solution, and decreased to 46.29 MPa afterward; the compressive strength of the sandstone of Jinshiyan groove decreased from 59.65 MPa to 43.62 $\mathrm{MPa}$; the compressive strength of the sandstones of Yangyuanshi stone pillar decreased from 39.52 MPa to 25.57 MPa; the compressive strength of the sandstones of groove near Tongtai natural bridge decreased from 29.28 $\mathrm{MPa}$ to 22.46 $\mathrm{MPa}$; the compressive strength of the sandstone of the Fengcheyan through cave decreased from 10.77 MPa to 3.71 $\mathrm{MPa}$. The experimental results suggest that the water erosion in a humid monsoon climate environment of South China would promote the development of flat grooves and caves in the Danxia landscape areas.

(3) The experimental results show that great variations exist in the resistance against freezing and thawing among the rocks from the research sites: the compressive strength of Jinshiyan groove is much lower than that of Yangyuanshi stone pillar and Fengcheyan through cave; both the wet and dry compressive strength of conglomerate is higher than that of sandstone, and the sandstone in compressive experiments showed instantaneous bursts while the conglomerate showed significant spalling; the specimens collected from the groove near Tongtai natural bridge showed no significant changes in the compressive experiments; the dry and wet compressive strength of conglomerate decreased significantly after freezing-thawing. In the Danxiashan region, frequent intense actions of freezing and thawing happened in the glacial and interglacial periods in Quaternary. Even in the present winter time with air temperature fluctuating around $0^{\circ} \mathrm{C}$, the quasi periglacial actions occur (Zhu, 1996). Accordingly, freezing and thawing actions in the region could have greatly promoted the development of flat grooves resulting from physical weathering and collapses. 
(4) The differences of uniaxial mechanical strength, the ability of resistance against erosion, freezing, and thawing of Danxia rocks are closely related to the physical composition and structure of rocks. The sandstone of Fengcheyan is fine-grained sandstone with well-developed intergranular porosity and poor consolidation and cementation, and the loose sands will peel from rocks even by touching. Although there are calcareous cements in the conglomerate of Fengcheyan, gravel particles account for about 50\% and only little iron filing cements are distributed at the edge of clastic particles in the form of a very thin film. The above results show that the compositional and structural defects are the fundamental reasons for why the sandstone and conglomerate in Fengcheyan through cave have the weakest compressive strength in Mt. Danxiashan. In contrast, conglomerates at Yangyuanshi stone pillar not only have calcite and ferruginous cements, but also contain polycrystal quartz, and therefore have the highest compressive strength.

(5) According to identifications of rock thin sections under a polarizing microscope as well as the XRF and ICP-MS determination and analysis, we found that the white spots and their surrounding red sandstones are highly similar in grain size, roundness, sedimentary structures, etc. Thus, the white spots must have resulted from secondary reactions within the red sandstone. As the red sandstone of the Danxia Formation is a kind of permeable rock, rainwater infiltrating from the surface into the rock can form many cylindrical seepage zones. As a result, the ions such as $\mathrm{K}^{+}, \mathrm{Zn}^{2+}, \mathrm{Ti}^{2+}, \mathrm{Cu}^{2+}$ and $\mathrm{PO}_{4}{ }^{3-}$ in the sandstone are prone to flowing towards and being enriched in the infiltration zones. In the reduction environment, the red $\mathrm{Fe}^{3+}$ is reduced to $\mathrm{Fe}^{2+}$ and leached away, resulting in bleaching and the formation of white spots at the seepage zones. Also, the role of microbes cannot be ignored, and that are currently being studied.

(6) According to the analysis of composition and structure of honeycomb caves in Yunvlnajiang Cave, the small through caves and honeycomb caves near the Mengjueguan of Jinshiyan and Bazhai areas, the development of small through caves and honeycomb caves on precipice walls might have been related to the infiltration zones. When water moving vertically through the cylindrical infiltration zones in sandstone rocks and coming across the aquiclude layer at the bottom, it would change directions and move laterally, which eventually leads to the formation of honeycomb caves and small through caves as a result of dissolution and collapses.

(7) By integrating the field investigations with the experimental analysis, we found that the development of the large horizontal grooves in Jinshiyan, Sengmao Peak and Chahu Peak might have experienced the following processes: a large groove, mainly located within the weak sandstone layer, was developed by the lateral erosion of spiral circulations at the river bend. The later tectonic uplift raised the groove above the river. Since then, the geologic structure was stable, and the lateral erosion of river flows formed the second groove right below the first one. Such a cycle repeated again and again and eventually multiple-level grooves developed.

(8) According to the analysis of squama stone and the bedrock underneath, we believe squama stone in Jinshiyan Temple should be formed by the percolation of rainwater through the bedrock, leading to the enrichment and recrystallization of $\mathrm{Ca}^{2+}$ and other minerals in the shape of grids. The greenish materials on some of the squama stone surfaces are algae and other microorganisms growing under the condition of high humidity in the caves. 
(9) It should be noted that the rock samples of Danxia landscape topographies in this study were mainly taken from $\mathrm{K}_{2} d$ Danxia Formation stratum except white spots which were sampled from $\mathrm{K}_{1} c$ Changba Formation. The $\mathrm{K}_{2} d$ Danxia Formation was about $1000 \mathrm{~m}$ thick and formed during the late Cretaceous dating back to $96 \mathrm{Ma}$ to $65 \mathrm{Ma}$. This $31 \mathrm{Ma}$ long period witnessed not only the dinosaur extinction event but also the frequent volcanic eruptions, acid rain events, climate changes of wet/dry and warm/cold. As a result, the stratum developed in this period in the Mt. Danxiashan region showed enormous lithological difference and experienced the Quaternary neotectonic movement and freezing-thawing alternation between glacial and interglacial stages. In a word, many internal and external forces jointly created and shaped the present unusual Danxia landscape topographies.

\section{Acknowledgements}

We appreciate the laboratory and field assistance of KONG Qingyou, LIU Di, YANG Li, WANG Xiaocui, FU Jingcheng, LIANG Guomin, MAO Xiaodong, FAN Dengfeng, LUO Jiehong, WU Huaan, TAN Ming, DAI Huibao, and XIE Zhangzhen.

\section{References}

Bureau of Geology of Foshan City and 706 Geological Team of Bureau of Geology of Guangdong Province, 2008. Geological Genesis of Danxia Landform in Mt. Danxiashan Global Geopark. Foshan: Bureau of Geology of Foshan City, Foshan, Guangdong. (in Chinese)

Charlton R, 2008. Fundamentals of Fluvial Geomorphology. London: Routledge.

Chen G, 1935. Red rock systems of Guangdong Province. The Science Quarterly of the National Sun Yat-sen University, 6(4): 1-30. (in Chinese)

Chen G, 1941. One explanation for the geomophogensis of white spot in red bed. Geological Review, 6(Suppl.3), 393-396. (in Chinese)

Chen G, Liu H, 1939. The geology of Gong River Basin in Jiangxi. Collected Papers of Geological Survey of Jiangxi Province, 2(2): 1-64. (in Chinese)

Chen S, Zhu C, Peng H et al., 2010. Anti-pressure experimental study on rocks in level cave of Jinshiyan of Danxiashan in Guangdong Province. Journal of Anhui Normal University (Natural Science), 33(2): 170-174. (in Chinese)

Cui Z, Li D, Liu G et al., 2001. Characteristics and planation surface formation environment of the red weathering crust in Hunan, Guangxi, Yunnan, Guizhou and Tibet. Science in China (Series D), 44(Suppl.): 162-175.

Davis W M, 1899. The geographical cycle. The Geographical Journal, 14(5): 481-504.

Guo F, Jiang Y, Hu Z et al., 2011. Evolution and genesis system features of Danxia landform in Longhushan World Geopark. Journal of Mountain Science, 29(2): 195-201. (in Chinese)

Huang J. 1982. A kind of basic mode of slope development of Danxia landform. Tropical Geomorphology, 1982, 3(2): 107-134. (in Chinese)

Huang J, 2010. Geomorphology of Mt. Danxiashan. Beijing: Science Press. (in Chinese)

Huang J, 2014. Simple list of China Danxia landform. Guangzhou: School of Geography and Planning of Sun Yat-Sen University, 2014. (in Chinese)

Huang J, Chen Z, Huang K, 1992. The definition and classification of Danxia landform. Tropical Geomorphology, (Suppl.): 37-39. (in Chinese)

Knopf A, 1948. The geosynclinal theory. Bulletin of the Geological Society of America, 59: 649-670.

Ma C, Zhu C, Peng H et al., 2006. Danxia landform genesis of the Qiyun Mountain, Anhui Province. Journal of Geographical Sciences, 16(1): 45-56. 
National Development and Reform Commission of the People’s Republic of China, 2007. DL/T5368-2007 Standards of Rock Experiment Procedures of Water Conservancy and Hydropower Engineering. Beijing: China Electric Power Press. (in Chinese)

Ministry of Transport of the People's Republic of China, 2005. Standards of JTGE41-2005 of Highway Engineering Rocks. Beijing: China Communications Press. (in Chinese)

Ouyang J, Zhu C, Peng H, 2011. A contrast introduction to Danxia landforms from a world-wide references for similar landforms. Scientia Geographica Sinica, 31(8): 996-1000. (in Chinese)

Ouyang J, Zhu C, Peng H et al., 2009. Types and spatial combinations of Danxia landform of Fangyan in Zhejiang Province. Journal of Geographical Sciences, 19: 631-640.

Peng H, 2001. Danxia geomorphology of China: A review. Chinese Science Bulletin, 46 (Suppl.): 38-44.

Peng H, Pan Z, Yan L et al., 2013. A review of the research on red beds and Danxia landform. Acta Geographica Sinica, 68(9): 1170-1181. (in Chinese)

Shi Y, Cai Z, Li J, 1989. The Problems of Quaternary Glacier and Environment in the East China. Beijing: Science Press. (in Chinese)

Zhang C, Zhang T, 1986. The characteristice of aeolian sandstone within red bed of old Tertiary in Danxia Mountain beauty spot of Renhua County, Guangdong. Minerals and Rocks, 6(3): 51-54. (in Chinese)

Zhao T, Zhao X, Peng H et al., 2014. A tentative discussion on the definition and classification of Danxia landform. Acta Geoscientica Sinica, 35(3): 375-382. (in Chinese)

Zhu C, 1996. Rates of periglacial processes in the Central Tianshan, China. Permafrost and Periglacial Processes, 7: 79-94.

Zhu C, 2000. A Study of Sedimentological Environments of the Eastern Mountainous Region in the Quaternary. Nanjing: Nanjing University Press. (in Chinese)

Zhu C, Peng H, Li Z et al., 2009. Age and genesis of the Danxia landform on Jianglang Mountain, Zhejiang Province. Journal of Geographical Sciences, 19: 615-630.

Zhu C, Peng H, Ouyang J et al., 2009. Age genesis and characteristics of Danxia landform of Fangyan in Zhejiang Province, China. Scientia Geographica Sinica, 29(2): 229-237. (in Chinese)

Zhu C, Peng H, Ouyang J et al., 2010. Rock resistance and the development of horizontal grooves on Danxia slopes. Geomorphology, 123: 84-96.

Zhu C, Yu J, Zhao N et al., 2000. Danxia landform genesis and scenic feature on Guanzai Mountain, Fujian Province. Acta Geographica Sinica, 55(6): 679-688. (in Chinese)

Zhu C, Xie Z, Li F et al., 2012. An Introduction to Global Change Science. Beijing: Science Press. (in Chinese) 